\title{
Unusually low genetic divergence at COI barcode locus between two species of intertidal Thalassaphorura (Collembola: Onychiuridae)
}

\author{
Xin Sun ${ }^{\text {Corresp., }}{ }^{1,2}{ }^{\text {, Anne Bedos }}{ }^{3}$, Louis Deharveng ${ }^{3}$ \\ ${ }^{1}$ Key Laboratory of Wetland Ecology and Environment, Northeast Institute of Geography and Agroecology, Chinese Academy of Sciences, Changchun, \\ China \\ 2 J.F. Blumenbach Institute of Zoology and Anthropology, University of Göttingen, Göttingen, Germany \\ 3 Institut de Systématique, Evolution, Biodiversité, ISYEB - UMR 7205 - CNRS, MNHN, UPMC, EPHE, Sorbonne Universités, Museum national d'Histoire \\ naturelle, Paris, France \\ Corresponding Author: Xin Sun \\ Email address: sunxin@iga.ac.cn
}

Species classification is challenging when the taxa display limited morphological differences. In this paper, we combined morphology and DNA barcode data to investigate the complicated taxonomy of two Onychiurid Collembolan species. Thalassaphorura thalassophila and $T$. debilis are among the most common arthropod species in intertidal ecosystems and are often considered to be synonymous. Based on morphological and barcode analyses of fresh material collected in their type localities, we show that each of them is the state of the species. However, their morphological distinctiveness was only supported by a molecular divergence much smaller than previously reported at the interspecific level among Collembola. This divergence was even smaller than interpopulation divergences recognized in the related edaphic species T. zschokkei, as well as those known between MOTUs within many Collembolan species. Our results may indicate a link between low genetic interspecific divergence and intertidal habitat, as the only biological peculiarity of the two species of interest compared to other Collembolan species analyzed to date is their strict intertidal life. 
1 Unusually low genetic divergence at COI barcode locus between two species of intertidal

2 Thalassaphorura (Collembola: Onychiuridae)

3

4 Xin Sun ${ }^{1,2}$, Anne Bedos ${ }^{3}$ and Louis Deharveng ${ }^{3}$

$5 \quad{ }^{1}$ Key laboratory of Wetland Ecology and Environment, Northeast Institute of Geography and

6 Agroecology, Chinese Academy of Sciences, Changchun 130012, China

7 2J.F. Blumenbach Institute of Zoology and Anthropology, University of Göttingen, 37073

8 Göttingen, Germany

9 Institut de Systématique, Evolution, Biodiversité, ISYEB - UMR 7205 - CNRS, MNHN, UPMC,

10 EPHE, Sorbonne Universités, Museum national d'Histoire naturelle, 45 rue Buffon, 75005 Paris,

11 France

13 Corresponding author:

14 Xin Sun ${ }^{1,2}$

$15{ }^{1}$ Key laboratory of Wetland Ecology and Environment, Northeast Institute of Geography and

16 Agroecology, Chinese Academy of Sciences, Changchun 130012, China. Tel:

$17+86(0) 43185542292$. Fax: $+86(0) 43185542298$

18 2J.F. Blumenbach Institute of Zoology and Anthropology, University of Göttingen, 37073

19 Göttingen, Germany

20 Email address: sunxin@iga.ac.cn 


\section{Abstract}

Species classification is challenging when the taxa display limited morphological differences. In this paper, we combined morphology and DNA barcode data to investigate the complicated taxonomy of two Onychiurid Collembolan species. Thalassaphorura thalassophila and T. debilis are among the most common arthropod species in intertidal ecosystems and are often considered to be synonymous. Based on morphological and barcode analyses of fresh material collected in their type localities, we show that each of them is the state of the species. However, their morphological distinctiveness was only supported by a molecular divergence much smaller than previously reported at the interspecific level among Collembola. This divergence was even smaller than inter-population divergences recognized in the related edaphic species $T$. zschokkei, as well as those known between MOTUs within many Collembolan species. Our results may indicate a link between low genetic interspecific divergence and intertidal habitat, as the only biological peculiarity of the two species of interest compared to other Collembolan species analyzed to date is their strict intertidal life.

\section{Introduction}

The intertidal zone, a narrow littoral strip between the low and high tide marks (Mouritsen \& Poulin, 2002; Raffaelli \& Hawkins, 2012), is a critical interface between terrestrial and aquatic ecosystems (Raffaelli \& Hawkins, 2012). It is characterized by daily cycles of submersion and exposure due to tidal movements. Environmental conditions in this ecosystem are therefore very predictable but extremely variable within a day. Many groups of marine origin, as well as some of terrestrial origin, include organisms that are well adapted to these harsh environmental conditions.

Springtails (Collembola) are the most abundant and often the most diversified hexapods in the intertidal environment (Deharveng, 2004; Joosse, 1976), where they are often found in very large numbers. This has been shown for Anurida maritima (Guérin, 1939) and several species of Thalassaphorura Bagnall, 1949 (Christiansen \& Bellinger, 1988; Willem, 1925; Witteveen \& Joosse, 1988). The genus Thalassaphorura is diverse and widely distributed. The taxonomic history of its intertidal species, traced in detail in Bellinger et al. (2015), is complex. Bagnall (1949) described the genus with Onychiurus thalassophilus Bagnall, 1937, as the type of species. A few species were subsequently described in or assigned to Thalassaphorura (Fjellberg, 1998; Pomorski, 1998), and various combinations and synonyms have been proposed (Bellinger et al., 
2015). Currently, 57 valid species are recognized in the genus (Kaprus' \& Paśnik, 2017; Sun, Bedos \& Deharveng, 2017), nine of which are halobionts or restricted to the intertidal zone (Arbea, 2017). Two of these intertidal species, namely, T. debilis and T. thalassophila, are widespread in the northern hemisphere. The intertidal ecology of these two species is well known (Moniez, 1890; Willem, 1925) compared to that of other species of the genus. Despite their unique habitat, the morphology of these species is similar to that of the non-intertidal species in the genus (Sun, Chen \& Deharveng, 2010), which live in litter and soil.

Due to different placements and synonymies, the taxonomic status of the two species has been confused for a long time. T. debilis was described as Lipura debilis Moniez 1890 and T. thalassophila as Onychiurus thalassophilus in 1937. The latter was collected from intertidal habitats in Scotland and was described as a species of the "debilis" group, differing from others by its vestigial unguiculus (Bagnall, 1937). Then, it was assigned as a type species of the genus Thalassaphorura by Bagnall (1949). The generic assignation of the species was subsequently much debated. It was placed in different genera, such as Onychiurus Gervais, 1841 by Stach (1954), Spelaphorura Bagnall, 1948 by Salmon (1959), and Protaphorura Absolon, 1901 by Gisin (1960) and Hopkin (1997), and then moved back to the genus Thalassaphorura by Pomorski (1998). The old species Lipura debilis Moniez, 1890 was assigned to Onychiurus by Bagnall (1935), Christiansen \& Bellinger (1988), Denis (1923) and Willem (1925), or to Protaphorura by Hopkin (1997) and Jordana et al. (1997). Fjellberg (1998) synonymized the two species after studying the type specimens of $T$. thalassophila and assuming that $T$. debilis is a morphologically variable species. However, re-examination of the type material and detailed studies of fresh specimens from type localities revealed consistent differences among the two species (Sun, Chen \& Deharveng, 2010).

The confusing taxonomy is due to insufficient detail in the earliest descriptions of the species, unjustified synonymies, the low number of distinguishing taxonomic characters and the lack of information on intraspecific variability within the species. The characters used in the taxonomy of Thalassaphorura are as follows: the number of pseudocelli on the head, body and legs; the number of papillae of sensory organ of antennal III segment; the relative length of unguiculus; the length of anal spines; the number of chaetae in distal whorl of tibiotarsi; and the morphology and number of S-chaetae on the head and body (Sun, Bedos \& Deharveng, 2017). Several of these characters are known to exhibit intra-specific polymorphism. More than sixty species have been assigned to 
the genus until now (Bellinger, Christiansen, \& Janssens, 1996-2018), but the taxonomic status of several species, including the intertidal species of interest here, remains uncertain (Stach, 1954; Kaprus' \& Paśnik, 2017; Sun, Bedos \& Deharveng, 2017). This taxonomic uncertainty hampers meaningful studies on intertidal communities of the western Palearctic seashores, where both species are among the dominant arthropods.

In an attempt to clarify the taxonomic status of these species, we combine detailed morphological and barcode analyses of the type populations of T. debilis and T. thalassophila. In the Collembola, DNA barcoding has been used to complement morphological characters to allow species characterization in several genera, including Deutonura (Porco, Bedos \& Deharveng, 2010), Heteromurus (Lukić et al., 2015), Homidia (Pan, Zhang \& Li, 2015), Lepidobrya (Zhang, Greenslade \& Stevens, 2017), Protaphorura (Sun et al., 2017), and Tomocerus (Zhang et al., 2014; Yu, Ding \& Ma, 2017). DNA-based approaches are regarded as powerful tools for species delimitation, especially in groups of closely related species with uncertain taxonomic status (Hebert et al., 2003). Although various molecular markers have been employed at the species level, a 658-base fragment of the mitochondrial gene cytochrome c oxidase I (COI), which is widely used for barcoding animals (Hajibabaei et al., 2007), has been effective in most zoological groups, including birds (Hebert et al., 2004), fish (Ward et al., 2005), cowries (Meyer \& Paulay, 2005), spiders (Barrett \& Hebert, 2005), and Lepidoptera (Hajibabaei, et al., 2006).

Large divergences $(>5 \%)$ in DNA barcode sequences provide strong support for the taxonomic separation of two putative species (Hebert et al., 2003). However, the extent of divergence between congeneric species varies among invertebrate groups (Hebert, Ratnasingham \& deWaard, 2003). Insects usually have lower interspecific divergences than non-winged arthropods. For example, average DNA barcode distances between congeneric species range from 7-8\% in holarctic Lepidoptera (Hebert \& Landry, 2010, Hausmann et al., 2011) and 9.3\% in Diptera (Hebert, Ratnasingham \& deWaard, 2003), to $11.5 \%$ in Hymenoptera and $13.9 \%$ in North America Ephemeroptera (Webb et al., 2012). In contrast, Collembola shows much higher divergence in COI sequences between congeneric species (Porco et al. 2012a; Yu et al., 2016), with reported values ranging from 16.35 to $24.55 \%$ (Tab. 1). These values are similar to divergence levels between the congeneric species of other non-winged soil invertebrates, such as Scolopendromorpha (13.7-22.2\% in Wesener et al., 2016) or Lithobiomorpha (13.7-24.5\% in Stoev et al., 2013). Furthermore, recent molecular studies on divergences within Collembolan 
117 species have revealed divergences almost as deep as among congeneric morphological species

118 (Cicconardi, Fanciulli \& Emerson, 2013; Emerson et al., 2011; Frati et al., 2000; Katz, Giordano

119

120

121

122

123

124

125

126

127

128

129

130

131

132

133

134

135

136

137

138

139

140

141

142

143

144

145

146

147

\& Soto-Adames, 2015; Porco et al., 2012b; Soto-Adames, 2002).

In this paper, we (i) re-describe and compare the two species T. debilis and T. thalassophila based on fresh specimens from their type localities, (ii) evaluate the congruence between DNA barcode and morphological data for the delimitation of the two species, and (iii) relate the unusually low genetic divergence with respect to clear morphological differences in the broader taxonomic and ecological context.

\section{Material \& methods}

Sampling

Sampling was done along the shores of Dalmeny in Scotland (type locality of T. thalassophila) and Pointe-aux-Oies in northwestern France (type locality of T. debilis) (Fig. 1). Both species were collected in the intertidal zone, where they lived in dense populations, in habitats characterized by very weak slope, rocky substrate, and abundant algae and barnacles on rocks. Specimens were picked up directly from under stones at low tide with a brush, or at the surface of the water after washing of gravels and stones in a plastic basin. Only T. thalassophila was present in the Dalmeny site, while the species co-occurred with T. debilis at Pointe-aux-Oies.

\section{DNA extraction and sequencing}

We successfully barcoded 41 specimens, including 26 Thalassaphorura debilis and $15 T$. thalassophila, from northwest France and Scotland, and 31 specimens belonging to 5 additional species (Supplementary Tab. 1), in order to illustrate the interspecific divergence among nonmarine species of the same genus. The species T. zschokkei was represented by 3 populations totaling 11 specimens, which were analyzed to evaluate between-populations of genetic divergence in a non-marine species living in mountain soils and mosses. Extraction and sequencing were done at the Biodiversity Institute of Ontario, University of Guelph (Ontario, Canada). DNA was extracted from entire specimens in $30 \mathrm{~mL}$ of lysis buffer and proteinase $\mathrm{K}$ incubated at $56^{\circ} \mathrm{C}$ overnight. DNA extraction followed a standard automated protocol using 96-well glass fiber plates (Ivanova, deWaard \& Hebert, 2006). Specimens were recovered after DNA extraction for further morphological examination according to the workflow detailed in (Porco et al., 2010). The 5' 
148 region of COI, including $658 \mathrm{bp}$ used as a standard DNA barcode, was amplified using M13 tailed primers LCO1490 and HCO2198 (Folmer, 1994). Samples that failed to generate an amplicon were subsequently amplified with a pair of internal primers combined with full-length ones, LepF1-MLepR1 and MLepF1- LepR1 (Hajibabaei et al., 2006). A standard PCR reaction protocol was used for amplification, and products were checked on a 2\% E-gel 96Agarose (Invitrogen). Unpurified PCR amplicons were sequenced in both directions using M13 tailed primers (Hajibabaei et al., 2005), with products subsequently purified using Agencourt CleanSEQ protocol and processed using BigDye ver. 3.1 on an ABI 3730 DNA Analyzer (Applied Biosystems). Sequences were assembled with Sequencer 4.5 (GeneCode Corporation, Ann Arbor, MI, USA) and aligned by eye using BIOEDIT ver. 7.0.5.3 (Hall, 1999). As we observed no indels in the COI sequences, sequence alignment was unambiguous. Sequences are publicly available on BOLD (Supplementary Tab. 1).

\section{Data analysis}

The K2P distances (Kimura, 1980) and the Neighbor-Joining tree (Saitou \& Nei, 1987) were calculated in MEGA7 (Kumar, Stecher \& Tamura, 2016) with 1000 pseudoreplicates and pairwise deletion and other parameters as the defaults. The frequency of $\mathrm{K} 2 \mathrm{P}$ distances was graphed in $\mathrm{R}$ 3.3.2. Divergence time was estimated using *BEAST (Heled \& Drummond 2010). Specimens were assigned to species a priori by the results of above species delimitations. An uncorrelated lognormal relaxed clock was selected for each partition, the GTR+G+I for substitution mode and the Yule process for speciation priors. In the absence of available fossil calibrations in Collembola, the substitution rate (3.36\% pairwise divergence per Mya) estimated by Papadopoulou et al. (2010) was employed. An MCMC chain was executed twice for 10 million generations with a sample frequency of 1,000 and the initial 5,000 discarded as burn-in. The ESS values and convergence were checked in Tracer v1.6 (Rambaut et al., 2014).

\section{Microscopic examination}

Sixty-one specimens (30 T. debilis and 31 T. thalassophila) preserved in 95\% ethanol and 25 skins retrieved following DNA extraction (16 T. debilis and 9 T. thalassophila) were mounted on slides in a Marc André II solution, after clearing in lactic acid. Six type specimens (the lectotype and 2 paralectotypes of $T$. debilis and 3 syntypes of $T$. thalassophila) were examined. Photos of 
specimens in alcohol were taken with a Jenoptik ProgRes C10+ camera mounted on a Leica MZ16. Slides were examined with a Leica DMLB microscope with DIC. A drawing was made through a camera lucida and improved with Photoshop Elements 9.

\section{Terminology and abbreviations}

Chaetotaxy of the labium, anal valves, and furca remnant is applied according to Fjellberg (1999), Yoshii (1996) and Weiner (1996), respectively. Tibiotarsal chaetotaxy is presented after Deharveng (1983) and is expressed as the total number of chaetae (number of chaetae in whorls $\mathrm{A}+\mathrm{T}, \mathrm{B}$, and $\mathrm{C}$, respectively). The unguiculus/unguis ratio is given according to the length of the medial line of unguiculus and the length of the inner edge of the unguis. The formulae of pseudocelli and pseudopores are presented as the number per half-tergum/sternum from head to Abd. V.

AIIIO — sensory organ of Ant. III, Abd.—abdominal segment, Ant.—antennal segment, AS— anal spine, ms - S-microchaeta, PAO — postantennal organ, pso-pseudocellus, psp - pseudopore, psx — parapseudocellus, Th.—-thoracic segment, $\mathrm{x}$ - ventro-axial psp of Abd. IV.

\section{Results}

FAMILY ONYCHIURIDAE BÖRNER, 1913

Genus THALASSAPHORURA BAGNALL, 1949

Type species: Onychiurus thalassophilus Bagnall, 1937 (Scotland)

\section{Remarks on synonymies among halophilous species :}

In his reference book on Onychiuridae, Stach (1954: 73) stated that "The synonymy of the species Lipura debilis Moniez, 1890 is very complicated". Although he introduced all the forms of T. debilis that had been validly described in his key, he expressed doubt regarding the proposed synonymies and stressed that all species "should be exactly examined". In this group with many closely related species, and in full agreement with Stach's idea, we do not accept most synonymies that have been perpetuated in the literature, as they are not supported by explicit morphological comparisons. The only exception is the synonymy $T$. thalassophila $=T$. debilis proposed by Fjellberg (1998); however, this proposal is challenged in the present paper on combined 
210 morphological and molecular ground. The synonymies that have to be re-assessed are the 211 following:

212 * Onychiurus imminutus Bagnall, 1937 is considered a synonym of Spelaphorura thalassophila 213 by Salmon (1959: 149), based on the examination of types, but without clear justification. As the 214 two species were collected in the same locality and are very similar, their synonymy is possible.

215 * Onychiurus littoralis Dürkop, 1935 is considered a synonym of Onychiurus debilis by Bagnall 216 (1937: 90, 145), without justification.

217 * Onychiurus litoreus Folsom, 1917 is considered a synonym of Onychiurus debilis by Denis 218 (1923: 216). This synonymy is challenged by Stach (1954: 74), and the species is listed as valid 219 by Christiansen \& Bellinger (1998: 463) under the name O. (Protaphorura) litoreus, but without 220 discussion of its possible synonymy.

221 * Aphorura neglecta Schaeffer, 1896 is considered a synonym of Onychiurus debilis by Denis 222 (1931: 209), but not by Stach (1954).

223

THALASSAPHORURA DEBILIS (MONIEZ, 1890)

Lipura debilis Moniez, 1890: 346

Aphorura neglecta Schaeffer, 1896: 112 after Denis (1931: 209, syn. dub.)

Onychiurus litoreus Folsom, 1917: 644 after Denis (1931: 209, syn. dub.) and Stach (1954: 74, syn. dub.)

Onychiurus debilis in Denis (1923: 216, redescription from syntypes)

Onychiurus debilis in Willem (1925: 279, redescription from specimens of the type locality)

Onychiurus littoralis Dürköp 1935: 133 after Bagnall (1937: 90, 145, syn. dub.)

Onychiurus debilis in Stach (1954: 73)

Handschiniella debilis in Salmon (1964: 162)

Onychiurus (Protaphorura) debilis in Bolger (1986: 193)

Jailolaphorura debilis in Weiner (1996: 178)

Protaphorura debilis in Skidmore (1995: 53)

Thalassaphorura debilis in Fjellberg (1998: 109)

Thalassaphorura debilis in Sun, Chen \& Deharveng (2010: 24) 
242 Material examined: Type material (examined). Denis (1923) listed eight specimens of

243

244

245

246

247

248

249

250

251

252

253

254

255

256

257

258

259

260

261

262

263

264

265

266

267

268

269

270

271

“Onychiurus debilis" in Moniez's collection. Only 5 were retrieved in the MNHN collection. Lectotype female and 2 paralectotype females on slides. Label, probably re-written by Denis, as «Coll. Moniez. Pointe-aux-Oies. 2.9.89». Two paralectotypes on slides (one female, one of undetermined sex). Label, probably re-written by Denis, as «Sous les Fucus. Pointe-aux-Oies. 1.9.89».

Non-type material from the type locality. France: Pas-de-Calais: Wimereux: Pointe-aux-Oies $\left(1.361623^{\circ} \mathrm{E}, 50.463582^{\circ} \mathrm{N}\right), 17 / 03 / 2010$, by hand and by washing of algae and sand, Sun Xin, Bedos A., Deharveng L. and Zon S. leg. (62-016, 3 males, 3 females, 1 juvenile on slides, including the skin of 1 male recovered after DNA extraction); same data (62-018, 3 males, 1 juvenile on slides, including the skins of 1 male and 1 juvenile recovered after DNA extraction). Ibid, 05/08/2010, by hand and by washing of algae and sand, Sun Xin leg. (62-044, 3 males, 3 females, 2 unsexed specimens, all on slides as skins of barcoded specimens recovered after DNA extraction); same data (62-045, 5 males, 12 females, 2 juveniles on slides, including the skins of 1 male, 3 females and 1 juvenile recovered after DNA extraction).

Redescription: Color: white. Length (without antennae): female 1.4-2.1 mm, male 1.4-1.65 mm. Body shape: cylindrical, slender, elongated, parallel-sided, with Abd. VI arched and anal spines 0.47-0.77 times as long as the inner edge of hind unguis (Figs 2A-B, 3A). Granulation of body surface: regular, with more or less distinctly thinner granules on intersegment areas.

Pseudocelli is 32/1-233/3,3-4,3,4-6,3-4 dorsally, 11/000/0111(2)0 ventrally and 2/2/2 on subcoxae I-III (Figs 3A, G, 4F). Parapseudocelli is absent. Pseudopores is 00/011/11110 dorsally, 00/111/000x0 ventrally (Figs 3A, G, 4F).

S-chaetae not distinguishable from ordinary chaetae. S-microchaetae tiny and blunt, as 0/011/000000 dorsally (Fig. 3A).

The antennal basal area is not well delimited by granulation. The antennae are approximately 1.1 times as long as head. The length ratio of antennal segments I: II: III: IV is approximately 1.0: 1.5: 1.5: 2.2. The antennal segment IV has subapical organite and basoexternal ms at approximately $1 / 3$ length from the base (Fig. 3D). The Ant. III sensory organ is composed of 5 papillae, 5 guard chaetae, 2 small sensory rods and 2 smooth sense clubs (Fig. 3C). Ant. III has external ms just behind sensory organ (Fig. 3C). Ant. II has 13 chaetae. Ant. I has 9 chaetae. 
272

273

274

275

276

277

278

279

280

281

282

283

284

285

286

287

288

289

290

291

292

293

294

295

296

297

298

299

300

301

302

PAO is composed of 13-21 (16.0 \pm 1.8 from 49 PAO) simple vesicles arranged in 2 rows along the axis of the organ (Fig. 3B). Dorsal cephalic chaeta $d_{0}$ is present (Fig. 3A). $3+3$ chaetae appear between two inner posterior pso, and $\mathrm{p}_{1}$ is anterior to others (Fig. 3A). The mandible has a strong molar plate and 4 apical teeth. The maxilla bears 3 teeth and 6 lamellae but is not examined in detail. The maxillary palp is simple with 1 basal chaeta and 2 sublobal hairs. The labral chaetae are 4/1,4,2. The labial papillae of AC type, papillae A-E are with 1, 4, 0, 3 and 2 guard chaetae, respectively (Fig. 3E). The labium has 6 proximal, 4 (E, F, G, and f) basomedial and 6 (a, b, c, d, e, e') basolateral chaetae. Postlabial chaetae are $4+4$ along the ventral groove.

The ordinary chaetae were differentiated in macro- and meso-chaetae. Th. I has 7-9+7-9 dorsal chaetae with frequent asymmetries (Fig. 3A, F). Th. II-III has 4-5+4-5 dorsal chaetae and Abd. I-III has 3-4+3-4 dorsal chaetae along the axial line, usually symmetrically arranged but with differences between specimens. Abd. IV-V has dorsal chaetae asymmetrically arranged along the axis; Abd. VI with $\mathrm{m}_{0}$ (Figs $3 \mathrm{~A}, 4 \mathrm{~F}$ ). Th. I-III has $1+1,1+1$ and $1+1$ ventral chaetae, respectively, between the coxae.

Subcoxa 1 has 4-5, 4-5, 4-5 chaetae, and subcoxa 2 has 1, 4, 4 chaetae on legs I-III, respectively (Fig. 3A). Tibiotarsal chaetae are $18(9,8,1), 18(9,8,1)$ and $18(9,8,1)$ chaetae on legs I-III, respectively (Fig. 4B-D). The unguis is without teeth. The unguiculus is short, only 0.27-0.47 times as long as the inner edge the of unguis, with inner basal lamella (Fig. 4B-D). The ventral tube has $1+1$ anterior chaetae, $7+7$ (rarely 7+8) distal chaetae and $2+2$ basal chaetae (Fig. $4 G)$. The furca was reduced to a finely granulated area, with 4 small chaetae in two rows posterior to the furcal rudiment (Figs 3G, 4E).

The genital plate consists of 15-18 chaetae in female (Fig. 3G), 35-50 in male. The anal valves have numerous acuminate chaetae; each lateral valve with chaetae $\mathrm{a}_{0}$ and $2 \mathrm{a}_{1}$; upper valve with chaetae $\mathrm{a}_{0}, 2 \mathrm{~b}_{1}, 2 \mathrm{~b}_{2}, \mathrm{c}_{0}, 2 \mathrm{c}_{1}, 2 \mathrm{c}_{2}$ (Fig. 4A).

Habitats: On the seashore, among Fucus and barnacles or under stones in the intertidal zone.

Remarks: The type material of T. debilis was in bad condition and only a few characters could be validated, i.e., the number of pso on Th. I tergum (2) and subcoxae I-III (2,2,2), the ratio of unguis/unguis (0.27-0.35), and the ratio of AS/unguis (0.55-0.57).

In the original description of the species by Moniez (1890), the figure of the unguiculus 
303

304

305

306

corresponds to $T$. debilis, as redefined here (approximately $1 / 3$ of claw length), as does the number of 23-28 vesicles in the PAO given in the text. The number of PAO vesicles in the Moniez' paratypes examined was not observable, but descriptions of the species by Denis (Denis, 1923) based on eight syntypes of Moniez and by Willem (Willem, 1925) and based on specimens from the type locality (Pointe-aux-Oies) state the number of vesicles as 20 and 17, respectively, which corresponds well with this redescription (Tab. 2). In the type locality, we found T. debilis was mixed with T. thalassophila, but in higher number. Therefore, it is possible that Moniez in 1890 included both species and described the unguiculus of a $T$. debilis and the PAO of a $T$. thalassophila.

Some characters of $T$. debilis are variable, especially the number of vesicles in the PAO (13$21)$, the number of dorsal pso (32/1-233/3,3-4,3,4-6,3-4), the number of pso on Abd. IV sternite ( 1 or 2$)$, the length of unguiculus (0.27-0.47 times as long as the inner edge of unguis) and the number of chaetae on subcoxa 1 of legs (4-5). However, the length of unguiculus (short but clearly longer than that of T. thalassophila) and the presence of pseudocelli on the abdominal sterna allow separation of the T. debilis from T. thalassophila. Fjellberg (1998) emphasized the former character in his work but apparently did not consider it as having a taxonomic value.

\section{THALASSAPHORURA THALASSOPHILA (BAGNALL, 1937)}

(Figures 2, 5-6, TABLE 2)

Onychiurus thalassophilus Bagnall (1937: 146)

Onychiurus imminutus Bagnall, 1937: 146 after Salmon (1959: 149, syn. dub.)

Thalassaphorura thalassophila in Bagnall (1949: 504)

Onychiurus thalassophilus in Stach (1954: 44)

Spelaphorura thalassophilus (sic) in Salmon (1959: 149)

Protaphorura debilis in Jordana et al. (1997: 571)

Thalassaphorura thalassophila in Pomorski (1998: 135)

Thalassaphorura debilis in Fjellberg (1998: 109) (synonymy not accepted here)

Material examined: Type material (examined). Three female syntypes of the Bagnall type series.

Great Britain, Scotland: Dalmeny Estate shore, well below the high-water mark, 12.V.35 (deposited in The Natural History Museum, London). 
334

335

336

337

Non-type material examined. Great Britain, Scotland: Dalmeny Estate shore $\left(3.310991^{\circ} \mathrm{E}\right.$, $\left.55.983110^{\circ} \mathrm{N}\right), 05 / 04 / 2016$, by hand and by washing of algae and sand, Sun Xin, Bedos A. and Deharveng L. (GB-011, 4 males, 11 females and 1 unsexed specimen on slides, including the skins of 1 male, 2 females and 1 unsexed specimen recovered after DNA extraction). France: Pas-deCalais: Wimereux: Pointe-aux-Oies $\left(1.361623^{\circ} \mathrm{E}, 50.463582^{\circ} \mathrm{N}\right), 17 / 03 / 2010$, by hand and by washing of algae and sand, Sun Xin, Bedos A., Deharveng L. and Zon S. leg. (62-016, 2 males and 1 female on slides, including the skin of 1 female recovered after DNA extraction); same data (62-017, 1 male, 1 female and 1 unsexed specimen on slides, including the skins of 1 male and 1 unsexed specimen recovered after DNA extraction). Ibid, 05/08/2010, by hand and by washing of algae and sand, Sun Xin leg. (62-044, the skin on slide of 1 female recovered after DNA extraction); same data (62-045, 3 males, 3 females and 3 juveniles on slides, including the skin of 1 juvenile recovered after DNA extraction).

Redescription: Color: white. Length (without antennae): female 1.32-1.93 mm; male 1.20-1.66 mm. Body shape: cylindrical, slender, elongated, parallel-sided, with Abd. VI arched and anal spines $0.68-1.08$ times as long as the inner edge of hind unguis (Figs 2C-D, 5A). Granulation of body surface: regular, with more or less distinctly thinner granules on intersegment areas.

Pseudocelli as 32/133/33343 dorsally, 11/000/00000 ventrally and 1/1/1 on subcoxae I-III (Figs 5A, F, 6A, F). Parapseudocelli absent. Pseudopores as 00/011/11110 dorsally, 00/111/000x0 ventrally (Figs 5A, F, 6A, F).

The S-chaetae is not distinguishable from ordinary chaetae. The S-microchaetae is tiny and blunt, as 0/011/000000 dorsally (Fig. 5F).

The antennal basal area is not well delimited by granulation. The antennae are as long as the head. The length ratio of antennal segments I: II: III: IV is approximately 1.0: 1.2: 1.2: 1.8. The antennal segment IV with subapical organite and basoexternal $\mathrm{ms}$ is at approximately $1 / 3$ length from the base. The Ant. III sensory organ is composed of 5 papillae, 5 guard chaetae, 2 small rods and 2 smooth clubs (Fig. 5D). Antennal segment III has external ms just behind sensory organ (Fig. 5D). Ant. II has 13 chaetae. Ant. I has 9 chaetae.

The PAO is composed of 16-23 (19.9 \pm 1.7 from 48 PAO) simple vesicles arranged in 2 rows along the axis of the organ (Fig. 5C). The dorsal cephalic chaeta $\mathrm{d}_{0}$ is present (Fig. 5A). $3+3$ chaetae appear between two inner posterior pso, while $\mathrm{p}_{1}$ is anterior to others (Fig. 5A). The mandible has 
365

366

367

368

369

370

371

372

373

374

375

376

377

378

379

380

381

382

383

384

385

386

387

a strong molar plate and 4 apical teeth. The maxilla bears 3 teeth and 6 lamellae but was not examined in detail. The maxillary palp is simple with 1 basal chaeta and 2 sublobal hairs. The labral chaetae are 4/1,4,2. The labial papillae are of AC type, papillae A-E with 1, 4, 0, 3 and 2 guard chaetae, respectively (Fig. 5B). The labium has 6 proximal, 4 (E, F, G, and f) basomedial and 6 (a, b, c, d, e, e') basolateral chaetae (Fig. 6A). The postlabial chaetae are 4+4 along the ventral groove.

Ordinary chaetae were differentiated in macro- and meso-chaetae. Th. I has 6-7+6-7 dorsal chaetae (frequent asymmetries) (Fig. 5A, E). Th. II-Abd. III has 3-4+3-4 dorsal chaetae along the axial line, usually symmetrically arranged but with differences between specimens. Abd. IV-V has dorsal chaetae asymmetrically arranged along the axis. Abd. VI has $\mathrm{m}_{0}$ and sometimes $\mathrm{a}_{0}$ present (Figs 5A, 6F). Th. I-III has 1+1, 1+1 and 1+1 ventral chaetae, respectively, between coxae.

Subcoxa 1 has 4, 4, 4 chaetae, and subcoxa 2 has 1, 4, 4 chaetae on legs I-III, respectively (Fig. 5A). Tibiotarsal chaetae has $18(9,8,1), 18(9,8,1)$ and $18(9,8,1)$ on legs I-III, respectively (Fig. 6B-D). The unguis is without teeth. The unguiculus very short, reduced to a minute, stumpy process and is 0.2 times as long as the inner edge of the unguis, with inner basal lamella (Fig. 6BD). The ventral tube has $1+1$ anterior chaetae, $7+7$ distal chaetae, and $2+2$ basal chaetae. The furca is reduced to a finely granulated area, with 4 small chaetae in two rows posterior to the furcal rudiment (Figs 5F, 6E).

The genital plate consists of 18-21 chaetae in females (Fig. 5F), and 40-42 in males. The anal valves have numerous acuminate chaetae; each lateral valve has chaetae $\mathrm{a}_{0}$ and $2 \mathrm{a}_{1}$; the upper valve has chaetae $a_{0}, 2 b_{1}, 2 b_{2}, c_{0}, 2 c_{1}, 2 c_{2}$ (Fig. 6G).

Habitats: Similar to T. debilis, on the seashore, among Fucus and barnacles or under stones in the intertidal zone.

Remarks: Thalassaphorura thalassophila is very similar to T. debilis by its habitus, nondifferentiated dorsal S-chaetae, and short unguiculus. However, it can be easily distinguished by several characters (Tab. 2): it has shorter unguiculus, reduced to a minute and stumpy process; the papillae of AIIIO are longer and slender; there are usually more vesicles in PAO (Fig. 7) there are no pso on the abdominal sterna; there are fewer chaetae on the subcoxae; and the AS is usually longer. We did not find significant intra-specific variations in the pso formula, and the size of the 
396

397

398

399

400

401

402

403

404

405

406

407

408

409

410

411

412

413

414

415

416

417

418

419

420

421

422

423

424

425

426

unguiculus among the studied specimens of $T$. thalassophila is contrary to those of $T$. debilis. Protaphorura debilis as redescribed by Jordana et al. (1997: 571) on Spanish material is probably T. thalassophila according to the diagnostic characters, except for the number of PAO vesicles, which could correspond to another species.

Overall, T. debilis and T. thalassophila represent two species that are closely related but morphologically clearly distinct based on standards of modern Onychiuridae taxonomy (Pomorski, 1998). Therefore, the two taxa are not synonymous as proposed by Fjellberg (1998: 109) (the author described the difference in unguiculus size between the two species, but did not consider it to be sufficient for separating them).

\section{Barcode characterization of the two species}

In total, 16 (62\% of barcoded specimens of $T$. debilis) and 9 (60\% of barcoded specimens of $T$. thalassophila) individuals were examined for morphological diagnostic characters after DNA extraction (Supplementary Tab. 1). The remaining specimens were damaged during DNA extraction and were therefore morphologically uninformative.

A small barcoding gap was observed at K2P distances of approximately 0.02 (Fig. 8). The two species Thalassaphorura debilis and T. thalassophila are clearly characterized by their barcode (Fig. 9), with a small inter-specific divergence of $4.3 \%$ and intra-specific divergence of $0.49 \%(0-1.9 \%)$ in T. debilis and $0.16 \%(0-0.3 \%)$ in T. thalassophila (Supplementary Fig. 1, Tabs 3-4). The two populations of T. thalassophila (France and Scotland) show a very low divergence $(0.03 \%)$. The non-intertidal species of Thalassaphorura exhibited much higher values of interspecific divergence (from $16.3 \%$ between T. bapen and T. encarpata to $22.6 \%$ between $T$. grandis and T. zschokkei), and very low intra-specific divergence, except in T. zschokkei (10.28\%), which is split in well-separated MOTUs that are morphologically indistinguishable (Tabs 3-4). Divergence time estimation indicated that the speciation event of the two species $T$. debilis and $T$. thalassophila occurred at 1.66 (0.47-3.14) Mya (Supplementary Fig. 2).

\section{Discussion}

In the present study, we used specimens from the type localities of Thalassaphorura debilis and T. thalassophila, as the state and age of the type material on slides that precluded extraction of reliable genetic material. The combined genetic and geographic pattern of the three analyzed 
427 populations (T. debilis, T. thalassophila France and T. thalassophila Scotland) can be summarized 428 as follows (Figs 9-10, Tab. 3): (i) moderate but clear molecular divergence between T. debilis 429 (France) and T. thalassophila (France and Scotland); (ii) very low molecular divergence between 430 T. thalassophila from France and T. thalassophila from Scotland in spite of the geographic 431 distance between them; and (iii) co-occurrence in syntopy of T. debilis and T. thalassophila in 432 France.

433 Morphology and genetic data were congruent in support for the species status of both taxa. However, the low level of genetic divergence between T. debilis and T. thalassophila was unusual when compared to genetic differences usually observed between congeneric species of Collembola (Tabs 3-4). Low genetic divergence associated with clear morphological differences is reported here for the first time in Collembola (Porco et al., 2012a; Porco et al., 2013). In Deutonura zana Deharveng, Zoughailech, Hamra-Kroua \& Porco, 2015, for instance, two populations geographically separated and genetically divergent at 3.7\% did not reveal any morphological difference despite a thorough examination (Deharveng et al., 2015).

For other species within the genus Thalassaphorura, the interspecific divergences we measured were in line with the high values observed for other Collembola, ranging from $16.4 \%$ to $22.6 \%$ between all couples of the 5 non-marine species, as well as between these species and each intertidal species (Tab. 4). The low divergence between T. debilis and T. thalassophila was more similar to that among many winged arthropods and lower than that among three populations of closely related, morphologically indistinguishable non-marine species (Figs 9-10, Tab. 4). This unusual pattern may be the result of our failure to detect discriminant morphological characters between populations of this last species. It also reflects different paces of morphological and molecular diversification among the Thalassaphorura species, which would potentially impact our understanding of intra- versus inter-specific variations among Collembola. Biologists using approaches for MOTU delimitations based on a barcode gap approach, e.g., ABGD (Puillandre et al., 2012), or on the use of a threshold derived from empirical data should be aware of such cases that may cause underestimation of actual diversity, as some species get overlooked.

The frequency of occurrence of the observed patterns is unknown and its origin obscure. It is probably not linked to phylogeny, as other Thalassaphorura species (Tab. 4) have divergences similar to other Collembolan genera. Furthermore, the estimated divergence time (0.47-3.14 Mya) between the two species is small compared to other species, suggesting that $T$. debilis and $T$. 
458 thalassophila could be two young sister species. The calibration method applied here is not 459 optimal, as it is based, in the absence of biogeographically informative pattern, on Tenebrionidae

460 beetles which probably have a much longer life cycle than Thalassaphorura. However, the $T$. zschokkei populations as well as other species of the genus analyzed here would have diverged much earlier. Therefore, the inference of a lower evolutionary pace of the $T$. debilis $-T$. thalassophila lineage cannot be ruled out. Because of these uncertainties, as well as the sympatric occurrence of the two species, the time of divergence for the two species cannot reliably be inferred.

High divergence in COI sequences between geographically distant MOTUs of the same morphological species is frequent in Collembola (Porco et al., 2013), especially among nonwidespread species. This is illustrated in the dataset analyzed by Porco et al. (2012a), where populations of several species drawn from various Collembolan families were represented by MOTUs, which diverged from conspecific MOTUs by 11.33 to $21.47 \%$ (with less than $2 \%$ intrapopulation divergence), matching, in most cases, the levels of divergence observed between congeneric species of Collembola. This may indicate the presence of yet unrecognized species, especially where the different MOTUs were found in sympatry. However, in several cases, such as for Bilobella aurantiaca (Caroli, 1912), thorough morphological analysis did not reveal morphological differences between conspecific MOTUs. We observed similarly high levels of divergence without morphological differentiation between three MOTUs of the non-marine species Thalassaphorura zschokkei (Fig. 10, Tab. 4), which were from populations 40 to $85 \mathrm{~km}$ apart and spread across the Southern Alps. Conversely, the two populations of T. thalassophila studied were $660 \mathrm{~km}$ apart (Fig. 1), but did not show genetic divergence at COI, which is similar to divergences often observed among widely distributed species that are suspected to be dispersed by humans (Porco et al., 2013). The common assumption is that marine currents might be a powerful dispersal agent for flightless littoral arthropods (Hawes et al., 2008; Witteveen \& Joosse, 1988), maintaining gene flow and explaining the very low genetic differentiation observed between populations. However, the link between wide distribution with efficient dispersal by ocean currents and low genetic divergence among populations is yet to be clearly documented for intertidal species.

The co-occurrence of two closely related species in the same microhabitat without apparent niche or trait differentiation is unusual. The two species are similar, and their minor morphological 
489

490

491

492

493

494

495

differences are probably not ecologically significant. Co-occurrences of genetically closely related and morphologically highly similar species are unknown among Collembola. When cooccurrences of morphological similar species have been reported, the taxonomic status of the species was uncertain, their microhabitat was slightly different (Rusek, 2007), or their distribution only overlapped in a narrow strip in a contact zone between parapatric forms (Deharveng et al., 1998). Therefore, the co-existence of the morphologically similar T. debilis and T. thalassophila in the same habitats should be further investigated.

The only evident biological feature that strongly separates our two species from non-marine Thalassaphorura is their peculiar intertidal ecology, as stressed above. Whether the debilis/thalassophila case is representative of genetic patterns associated with this environment will have to be investigated in other Collembola. However, aside from the intertidal species group of Anurida maritima, very few genera or species groups are known to involve marine and nonmarine species and to encompass closely related intertidal forms.

\section{Acknowledgements}

We thank Serge Zon from the Cocody University (Abidjan, Ivory Coast) for his help in field sampling; Wanda Maria Weiner from the Polish Academy of Sciences (Krakow) for helpful advice on the species taxonomy; Paul Brown from The Natural History Museum, London for the loan of the type material of T. thalassophila; David Porco from the Musée National d'Histoire Naturelle, Luxembourg; Marianne Elias and Rodolphe Rougerie from the Muséum National d'Histoire Naturelle, Paris; Feng Zhang from Nanjing Agricultural University for useful comments during the preparation of the manuscript; and Gunnar Keppel from University of South Australia for the language modification.

\section{References}

Arbea I. 2017. Una nueva especie litoral de Thalassaphorura Bagnall, 1949 (Collembola: Onychiuridae) de Pontevedra, noroeste de la Península Ibérica. Arquivos Entomolóxicos 17: 321-328.

Bagnall RS. 1935. Contributions towards a knowledge of the Scottish Onychiuridae (Collembola), I. Scottish Naturalist 214: 111-117.

Bagnall RS. 1937. Contributions towards a knowledge of the Scottish Onychiuridae (Collembola), 
II. The Scottish Naturalist May-June:146-150.

521

522

523

524

525

526

527

528

529

530

531

532

Bagnall RS. 1949. Contributions toward a knowledge of the Onychiuridae (CollembolaOnychiuroidea). V-X. Annals and Magazine of Natural History 12: 498-511.

Barrett RDH, Hebert PDN. 2005. Identifying spiders through DNA barcodes. Canadian Journal of Zoology 83: 481-491.

Bellinger PF, Christiansen KA, Arbea J, Janssens F. 2015. Checklist of the Collembola: Collembola species catalogue. http://www.collembola.org/publicat/bellingr/indexx.htm.

Bellinger PF, Christiansen KA, Janssens F. 1996-2018. Checklist of the Collembola of the World. http://www.collembola.org.

Bolger T. 1986. The Collembola of Ireland: A Checklist and Bibliography. Proceedings of the Royal Irish Academy. Section B: Biological, Geological, and Chemical Science 86(B): 183-218.

Christiansen K, Bellinger P. 1988. Marine littoral collembola of North and Central America. Bulletin of Marine Science 42: 215-245.

Christiansen K, Bellinger PF. 1998. Collembola of North America, north of the Rio Grande. Iowa: Grinnell College.

Cicconardi F, Fanciulli PP, Emerson BC. 2013. Collembola, the biological species concept and the underestimation of global species richness. Molecular ecology 22: 5382-5396.

Deharveng L. 1983. Morphologie évolutive des Collemboles Neanurinae en particulier de la lignée néanurienne. Travaux du Laboratoire d'Ecobiologie des Arthropodes Edaphiques, Toulouse 4: 1-63.

Deharveng L. 2004. Recent advances in Collembola systematics. Pedobiologia 48: 415-433.

Deharveng L, Bedos A, Gisclard C. 1998. Environmental factors, microgeographic patterns of endemism and hybrid zones in Monobella grassei (Insecta: Collembola: Neanuridae). Biological Journal of the Linnean Society 64: 527-554.

Deharveng L, Zoughailech A, Hamra-Kroua S, Porco D. 2015. A new species of Deutonura (Collembola: Neanuridae: Neanurinae) from north-eastern Algeria, and characterisation of two intraspecific lineages by their barcodes. Zootaxa 3920: 281-290.

Denis J. 1923. Notes sur les Aptérygotes. Annales de la Société Entomologique de France 14: 209-246.

Denis J. 1931. Collemboles des Collections C. Schäffer et du Zoologisches Staatsinstitut und 
Zoologisches Museum in Hamburg. Zoologisches Staatsinstitut und Zoologisches Museum in Hamburg 44: 197-242.

Emerson BC, Cicconardi F, Fanciulli PP, Shaw PJ. 2011. Phylogeny, phylogeography, phylobetadiversity and the molecular analysis of biological communities. Philosophical Transactions of the Royal Society of London B: Biological Sciences 366: 2391-2402.

Fjellberg A. 1998. The Collembola of Fennoscandia and Denmark: Part I Poduromorpha. Fauna Entomologica Scandinavica 35:.1-183.

Fjellberg A. 1999. The labial palp in Collembola. Zoologischer Anzeiger 237: 309-330.

Folmer O, Black M, Hoeh W, Lutz R, Vrijenhoek R. 1994. DNA primers for amplification of mitochondrial cytochrome c oxidase subunit I from diverse metazoan invertebrates. Molecular marine biology and biotechnology 3: 294-299.

Frati F, Dell'Ampio E, Casasanta S, Carapelli A, Fanciulli PP. 2000. Large amounts of genetic divergence among Italian species of the genus Orchesella (Insecta, Collembola) and the relationships of two new species. Molecular Phylogenetics and Evolution 17: 456-461.

Gisin H. 1960. Collembolenfauna Europas. Genève: Museum d'Histoire Naturelle.

Hajibabaei M, Ivanova NV, Ratnasingham S, Dooh RT, Kirk SL, Mackie PM, Hebert PDN. 2005. Critical factors for assembling a high volume of DNA barcodes. Philosophical Transactions of the Royal Society of London B: Biological Sciences 360: 1959-1967.

Hajibabaei M, Janzen DH, Burns JM, Hallwachs W, Hebert PDN. 2006. DNA barcodes distinguish species of tropical Lepidoptera. Proceedings of the National Academy of Sciences of the United States of America 103: 968-971.

Hajibabaei M, Singer GAC, Hebert PDN, Hickey DA. 2007 DNA barcoding: how it complements taxonomy, molecular phylogenetics and population genetics. Trends in Genetics 23(4): 167-172.

Hall TA. 1999. BioEdit: a user-friendly biological sequence alignment editor and analysis program for Windows 95/98/NT. Nucleic acids symposium series 41: 95-98.

Hausmann A, Haszprunar G, Segerer AH, Speidel W, Behounek G, Hebert PDN. 2011. Now DNA-barcoded: the butterflies and larger moths of Germany. Spixiana 34: 47-58.

Hawes T, Worland M, Bale J, Convey P. 2008. Rafting in Antarctic collembola. Journal of Zoology 274: 44-50.

Hebert PDN, Cywinska A, Ball SL, deWaard JR. 2003. Biological identifications through DNA 
barcodes. Proceedings of the Royal Society London B 270: 313-321.

583

584

585

Hebert PDN, Landry J-F. 2010. DNA barcodes for 1/1000 of the animal kingdom. Biology letters 6: 359-362.

Hebert PDN, Ratnasingham S, deWaard JR. 2003. Barcoding animal life: cytochrome c oxidase subunit 1 divergences among closely related species. Proceedings of the Royal Society London B 270(suppl 1): 596-599.

Hebert PDN, Stoeckle MY, Zemlak TS, Francis CM. 2004. Identification of birds through DNA barcodes. PLoS Biolology 2(10): e312.

Heled J, Drummond AJ. 2010. Bayesian inference of species trees from multilocus data. Molecular Biology and Evolution 27: 570-580.

Hopkin SP. 1997. Biology of the springtails (Insecta: Collembola). Oxford; New York; Tokyo: Oxford University Press.

Ivanova NV, Dewaard JR, Hebert PDN. 2006. An inexpensive, automation - friendly protocol for recovering high - quality DNA. Molecular Ecology Resources 6: 998-1002.

Joosse EN. 1976. Littoral apterygotes (Collembola and Thysanura). In: Cheng L, ed. Marine insects. New York: American Elsevier, 151-186.

Jordana R, Arbea JI, Simón C, Luciáñez MJ. 1997. Collembola Poduromorpha, Familia Onychiuridae, Subfamilia Onychiurinae. In: Ramos MA et al. eds. Fauna Ibérica. Vol. 8. Madrid: Museo Nacional de Ciencias Naturales, Consejo Superior de Investigaciones Cientificas; 477-641.

Kaprus’ I, Paśnik G. 2017. New Siberian “spineless” species of Thalassaphorura Bagnall, 1949 (Collembola, Onychiuridae), with a key to world species of the genus. Zootaxa 4362: 225245.

Katz AD, Giordano R, Soto-Adames FN. 2015. Operational criteria for cryptic species delimitation when evidence is limited, as exemplified by North American Entomobrya (Collembola: Entomobryidae). Zoological Journal of the Linnean Society 173: 818-840.

Kimura M. 1980. A simple method for estimating evolutionary rates of base substitutions through comparative studies of nucleotide sequences. Journal of molecular evolution 16: 111-120.

Kumar S, Stecher G, Tamura K. 2016. MEGA7: Molecular Evolutionary Genetics Analysis version 7.0 for bigger datasets. Molecular Biology and Evolution 33: 1870-1874.

Lukić M, Porco D, Bedos A, Deharveng L. 2015. The puzzling distribution of Heteromurus 
(Verhoeffiella) absoloni Kseneman, 1938 (Collembola: Entomobryidae: Heteromurinae) resolved: Detailed redescription of the nominal species and description of a new species from Catalonia (Spain). Zootaxa 4039: 249-275.

Meyer CP, Paulay G. 2005. DNA barcoding: error rates based on comprehensive sampling. PLoS Biology 3: e422.

Moniez R. 1890. Acariens et insectes marins des côtes du Boulonnais. Revue Biologique du Nord de la France 2: 338-350.

Mouritsen KN, Poulin R. 2002. Parasitism, community structure and biodiversity in intertidal ecosystems. Parasitology 124(7): 101-117.

Pan ZX, Zhang F, Li YB. 2015. Two closely related Homidia species (Entomobryidae, Collembola) revealed by morphological and molecular evidence. Zootaxa 3918: 285-294.

Papadopoulou A, Anastasiou I, Vogler AP. 2010. Revisiting the insect mitochondrial molecular clock: the Mid-Aegean Trench calibration. Molecular Biology and Evolution 27: 16591672.

Pomorski RJ. 1998. Onychiurinae of Poland (Collembola: Onychiuridae). Genus 9: 1-201.

Porco D, Bedos A, Deharveng L. 2010. Cuticular compounds bring new insight in the post-glacial recolonization of a Pyrenean area: Deutonura deficiens Deharveng, 1979 complex, a case study. PLoS ONE 5: e14405.

Porco D, Bedos A, Greenslade P, Janion C, Skarżyński D, Stevens M, van Vuuren BJ, Deharveng L. 2012a. Challenging species delimitation in Collembola: cryptic diversity among common springtails unveiled by DNA barcoding. Invertebrate Systematics 26: 470-477.

Porco D, Potapov M, Bedos A, Busmachiu G, Weiner WM, Hamra-Kroua S \& Deharveng L. 2012b. Cryptic diversity in the ubiquist species Parisotoma notabilis (Collembola, Isotomidae): a long used chimeric species? PLoS One, 7(9): e46056.

Porco D, Decaëns T, Deharveng L, James SW, Skarżyński D, Erséus C, Butt KR, Richard B, Hebert PDN. 2013. Biological invasions in soil: DNA barcoding as a monitoring tool in a multiple taxa survey targeting European earthworms and springtails in North America. Biological Invasions 15: 899-910.

Porco D, Rougerie R, Deharveng L, Hebert PDN. 2010. Coupling non - destructive DNA extraction and voucher retrieval for small soft - bodied Arthropods in a high - throughput context: the example of Collembola. Molecular Ecology Resources 10: 942-945. 
644 Puillandre N, Lambert A, Brouillet S, Achaz G. 2012. ABGD, Automatic Barcode Gap Discovery

645

646

647

648

649

650

651

652

653

654

655

656

657

658

659

660

661

662

663

664

665

666

667

668

669

670

671

672

673

674 for primary species delimitation. Molecular ecology 21: 1864-1877.

Raffaelli D, Hawkins SJ. 2012. Intertidal ecology. London: Kluwer Academic Publishers.

Rambaut A, Suchard MA, Drummond AJ. 2014. Tracer v1.6. Available from: URL http://tree.bio.ed.ac.uk/software/tracer/ (last accessed March 12, 2018).

Rusek J. 2007. Integration of ecological and morphological studies: Micro-distribution of. Protaphorura-species (Collembola: Onychiurinae) around a beech stem. In: Tajovsky K, Schlaghamersky J, Pizl V, eds. Contributions to Soil Zoology in Central Europe II. Ceske Budejovice, 117-120.

Saitou N, Nei M. 1987. The neighbor-joining method: a new method for reconstructing phylogenetic trees. Molecular Biology and Evolution 4: 406-425.

Salmon JT. 1959. Concerning the Collembola Onychiuridae. Ecological Entomology 111: 119156.

Salmon JT. 1964. An index to the Collembola. Royal Society of New Zealand Bulletin 7(2): 145644.

Skidmore R. 1995. Checklist of Collembola (Insecta: Apterygota) of Canada and Alaska. Proceedings of the Entomological Society of Ontario 45-76.

Soto-Adames FN. 2002. Molecular phylogeny of the Puerto Rican Lepidocyrtus and Pseudosinella (Hexapoda: Collembola), a validation of Yoshii's "color pattern species". Molecular Phylogenetics and Evolution 25: 27-42.

Stach J. 1954. The Apterygotan fauna of Poland in relation to the world-fauna of this group of Insects, Family: Onychiuridae. Krakow: Polska Akademia Nauk Instytut Zoologiczny.

Stoev P, Komerički MA, Akkari N, Liu MS, Zhou MX, Weigand AM, Hostens J, Hunter MCI, Edmunds SC, Porco D. 2013. Eupolybothrus cavernicolus Komerički \& Stoev sp. n. (Chilopoda: Lithobiomorpha: Lithobiidae): the first eukaryotic species description combining transcriptomic, DNA barcoding and micro-CT imaging data. Biodiversity data journal 1: e1013.

Sun X, Bedos A, Deharveng L. 2017. Two new species of the genus Thalassaphorura Bagnall, 1949 (Collembola: Onychiuridae) from south China, with an updated key to world species of the genus. Zootaxa 4338: 319-332.

Sun X, Chen J-X, Deharveng L. 2010. Six new species of Thalassaphorura (Collembola, 
Onychiuridae) from southern China, with a key to world species of the genus. Zootaxa 2627: 20-38.

Sun X, Zhang F, Ding Y, Davies TW, Li Y, Wu D. 2017. Delimiting species of Protaphorura (Collembola: Onychiuridae): integrative evidence based on morphology, DNA sequences and geography. Scientific Reports 7: 8261.

Ward RD, Zemlak TS, Innes BH, Last PR, Hebert PDN. 2005. DNA barcoding Australia's fish species. Philosophical Transactions of the Royal Society 360, 1847-1857.

Webb JM, Jacobus LM, Funk DH, Zhou X, Kondratieff B, Geraci CJ, DeWalt RE, Baird DJ, Richard B, Phillips I. 2012. A DNA barcode library for North American Ephemeroptera: progress and prospects. PLoS One 7: e38063.

Weiner WM. 1996. Generic revision of Onychiurinae (Collembola: Onychiuridae) with a cladistic analysis. Annales de la Société Entomologique de France 32: 163-200.

Wesener T, Voigtländer K, Decker P, Oeyen JP, Spelda J. 2016. Barcoding of Central European Cryptops centipedes reveals large interspecific distances with ghost lineages and new species records from Germany and Austria (Chilopoda, Scolopendromorpha). Zookeys 564: $21-46$.

Willem V. 1925. Les Collemboles marins de Wimereux. Travaux de la Station Zoologique de Wimereux 9: 275-283.

Witteveen J, Joosse E. 1988. The effects of inundation on marine littoral Collembola. Ecography 11: $1-7$.

Yoshii R. 1996. Identity of some Japanese Collembola “Deuteraphorura” Group of Onychiuruscontinued. Annals of the speleological research institute of Japan (Iwaizumi) 14: 1-15.

Yu D, Ding Y, Ma Y. 2017. Revision of Tomocerus similis Chen \& Ma, with discussion of the kinoshitai complex and the distal tibiotarsal chaetae in Tomocerinae (Collembola, Tomoceridae). Zootaxa 4268: 395-410.

Yu D, Zhang F, Stevens MI, Yan Q, Liu M, Hu F. 2016. New insight into the systematics of Tomoceridae (Hexapoda, Collembola) by integrating molecular and morphological evidence. Zoologica Scripta 45: 286-299.

Zhang F, Greenslade P, Stevens MI. 2017. A revision of the genus Lepidobrya Womersley (Collembola: Entomobryidae) based on morphology and sequence data of the genotype. Zootaxa 4221: 523-536. 
706 Zhang F, Yu D, Luo Y, Ho SYW, Wang B, Zhu C. 2014. Cryptic diversity, diversification and vicariance in the two species complexes of Tomocerus (Collembola, Tomoceridae) from China. Zoologica Scripta 43: 393-404. 
Figure 1

Location of sampling sites.

(1) Pointe-aux-Oies in France. (2) Dalmeny in Scotland. 


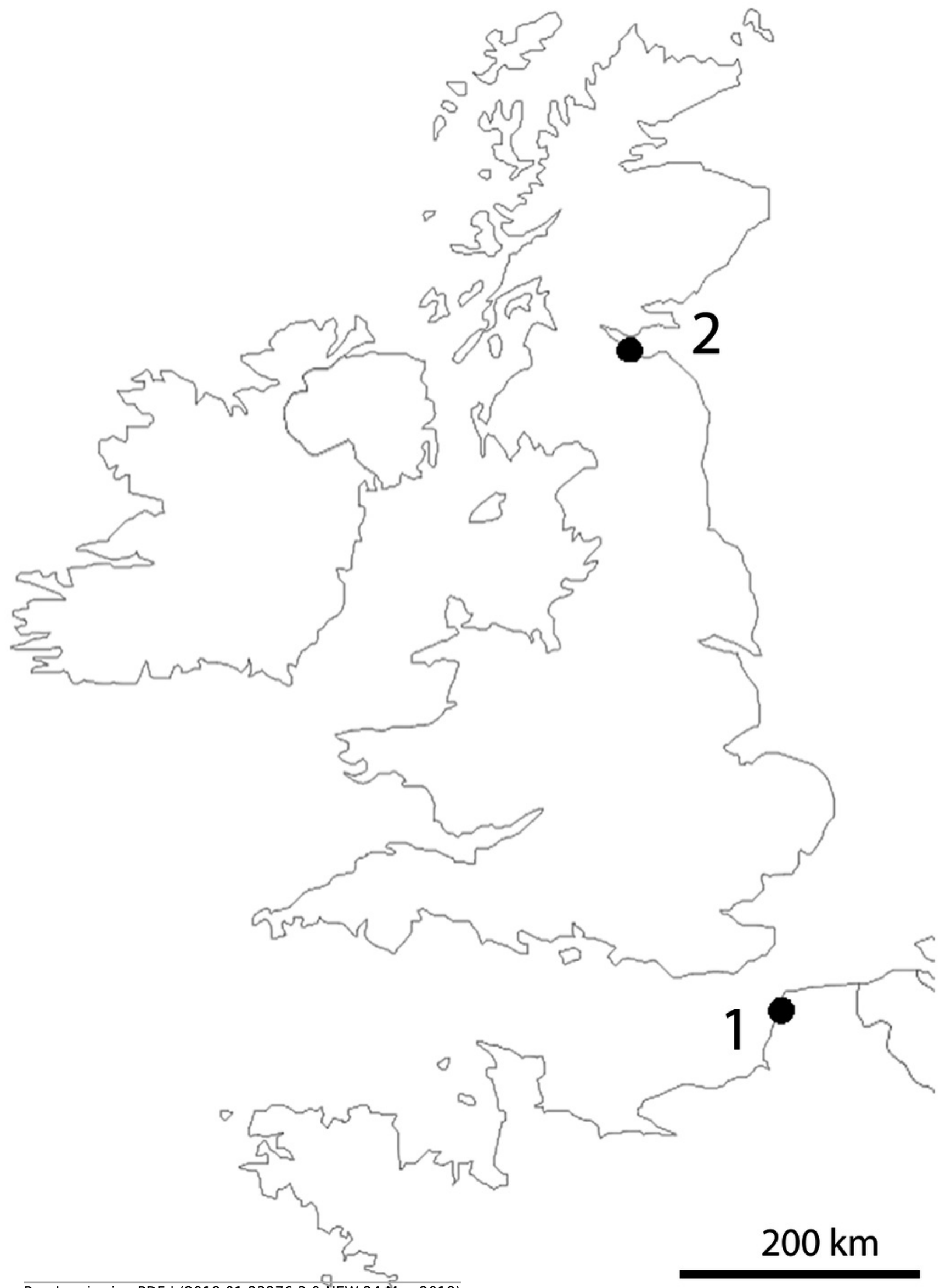




\section{Figure 2}

Species habitus in ethanol.

(A, B) Thalassaphorura debilis (Moniez, 1890). (C, D) Thalassaphorura thalassophila (Bagnall, 1937). Photos by L. Deharveng \& A. Bedos.

*Note: Auto Gamma Correction was used for the image. This only affects the reviewing manuscript. See original source image if needed for review.

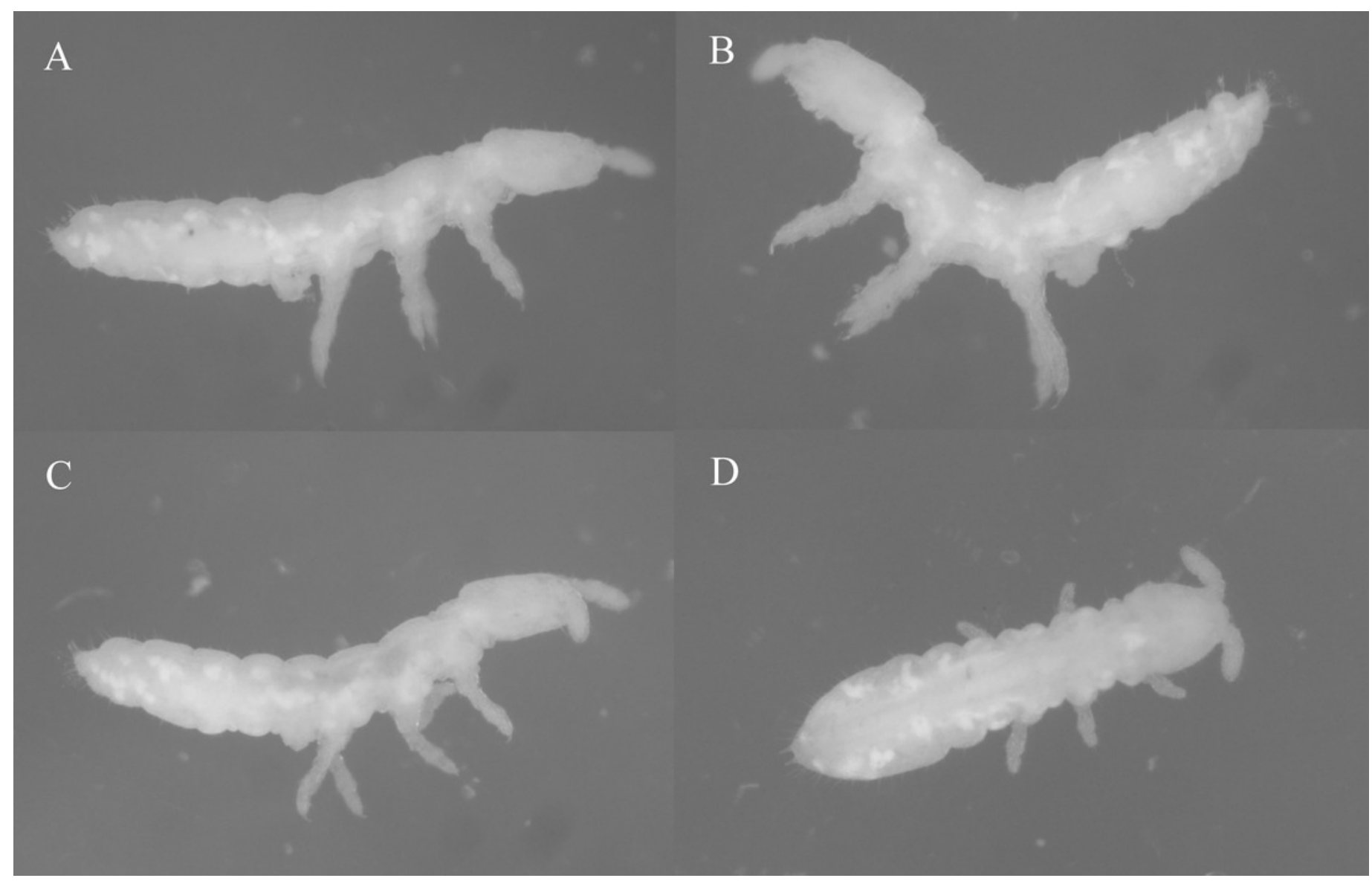




\section{Figure 3}

Thalassaphorura debilis.

(A) Habitus, pseudopores and dorsal chaetotaxy of head and body. (B) Postantennal organ.

(C) Ant. III sensory organ. (D) Antennal segments III and IV. (E) Labium. (F) Th. I tergum. (G)

Abdominal II-VI sterna. Scales: $0.1 \mathrm{~mm}(\mathrm{~A}, \mathrm{G}), 0.05 \mathrm{~mm}$ (D, F), $0.01 \mathrm{~mm}(\mathrm{~B}, \mathrm{C}, \mathrm{E})$. 


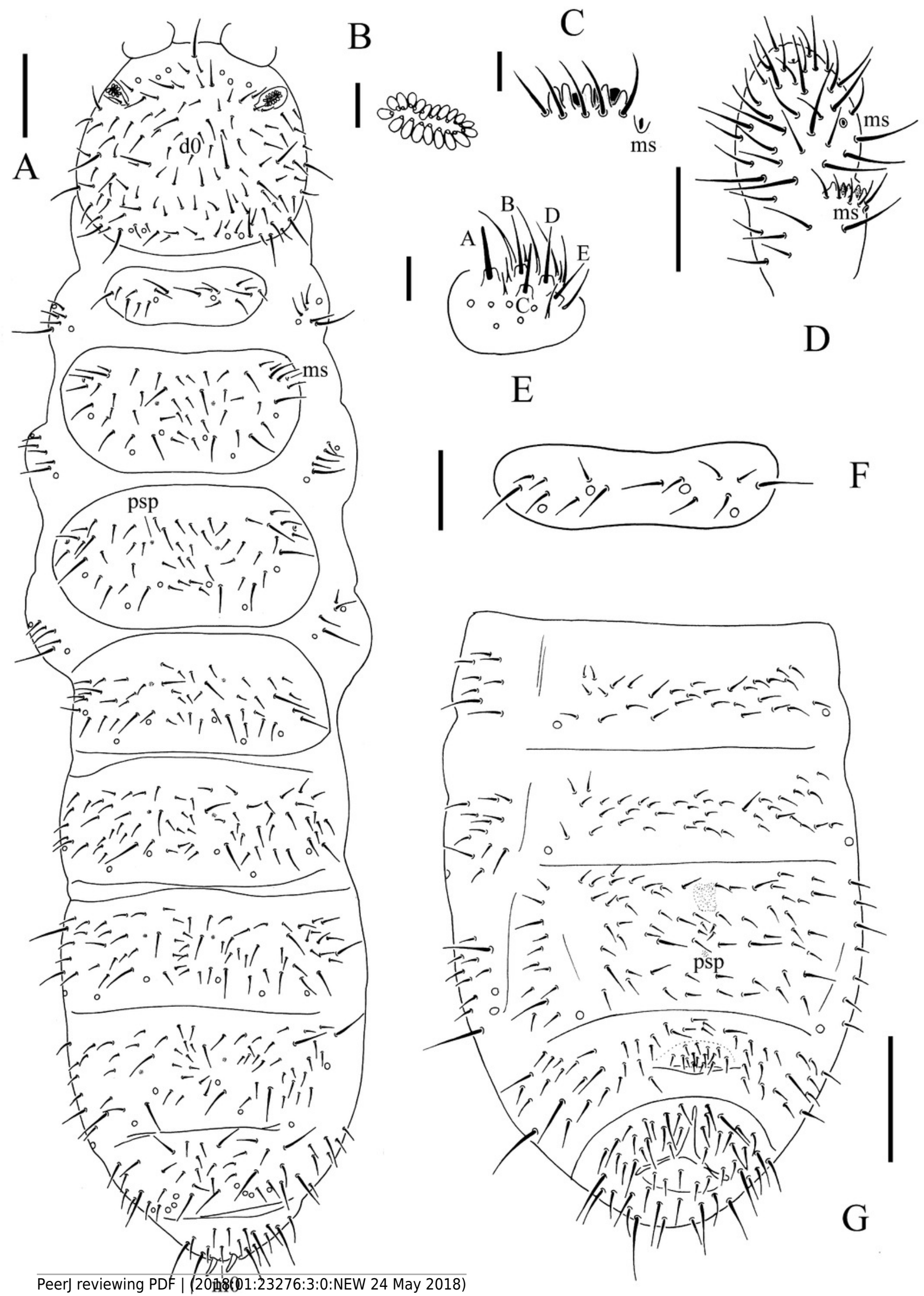


Figure 4

Thalassaphorura debilis.

(A) Anal valves. (B) Tibiotarsal chaetotaxy and claw of leg I. (C) Tibiotarsal chaetotaxy and claw of leg II. (D) Tibiotarsal chaetotaxy and claw of leg III. (E) Abd. IV sternum. (F) Abd. IV-VI terga. (G) Ventral tube. Scales: $0.1 \mathrm{~mm}(\mathrm{~A}, \mathrm{E}, \mathrm{F}), 0.05 \mathrm{~mm}(\mathrm{~B}, \mathrm{C}, \mathrm{D}, \mathrm{G})$. 


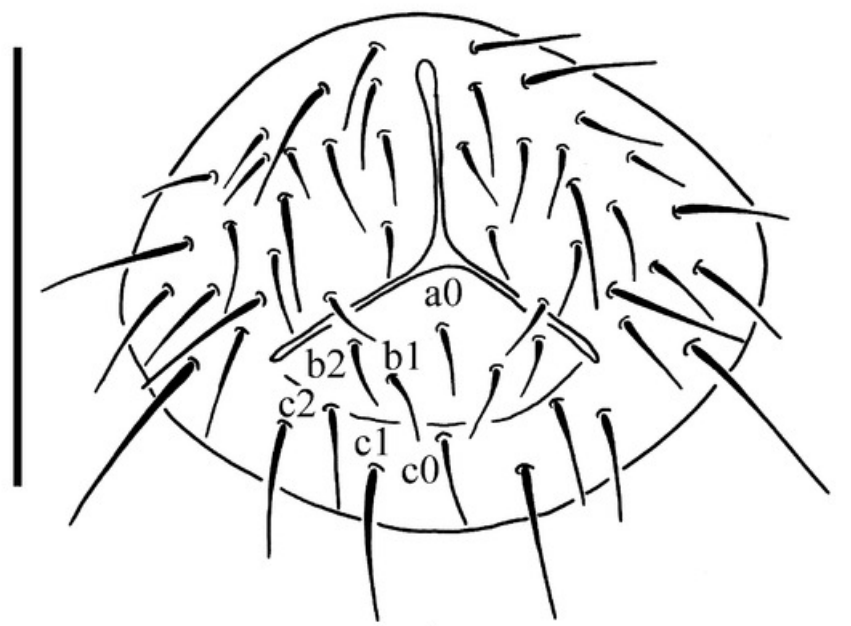

A

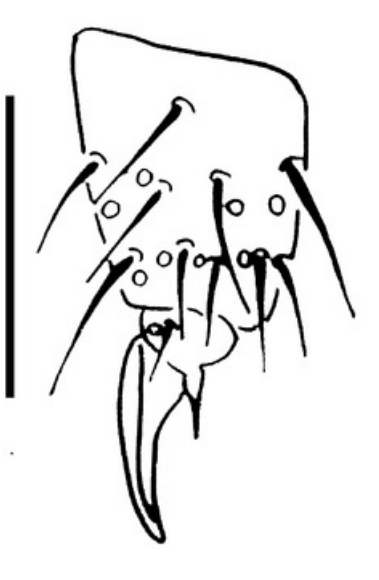

B

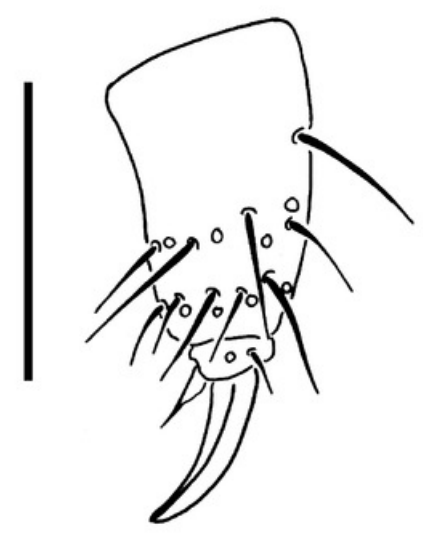

C
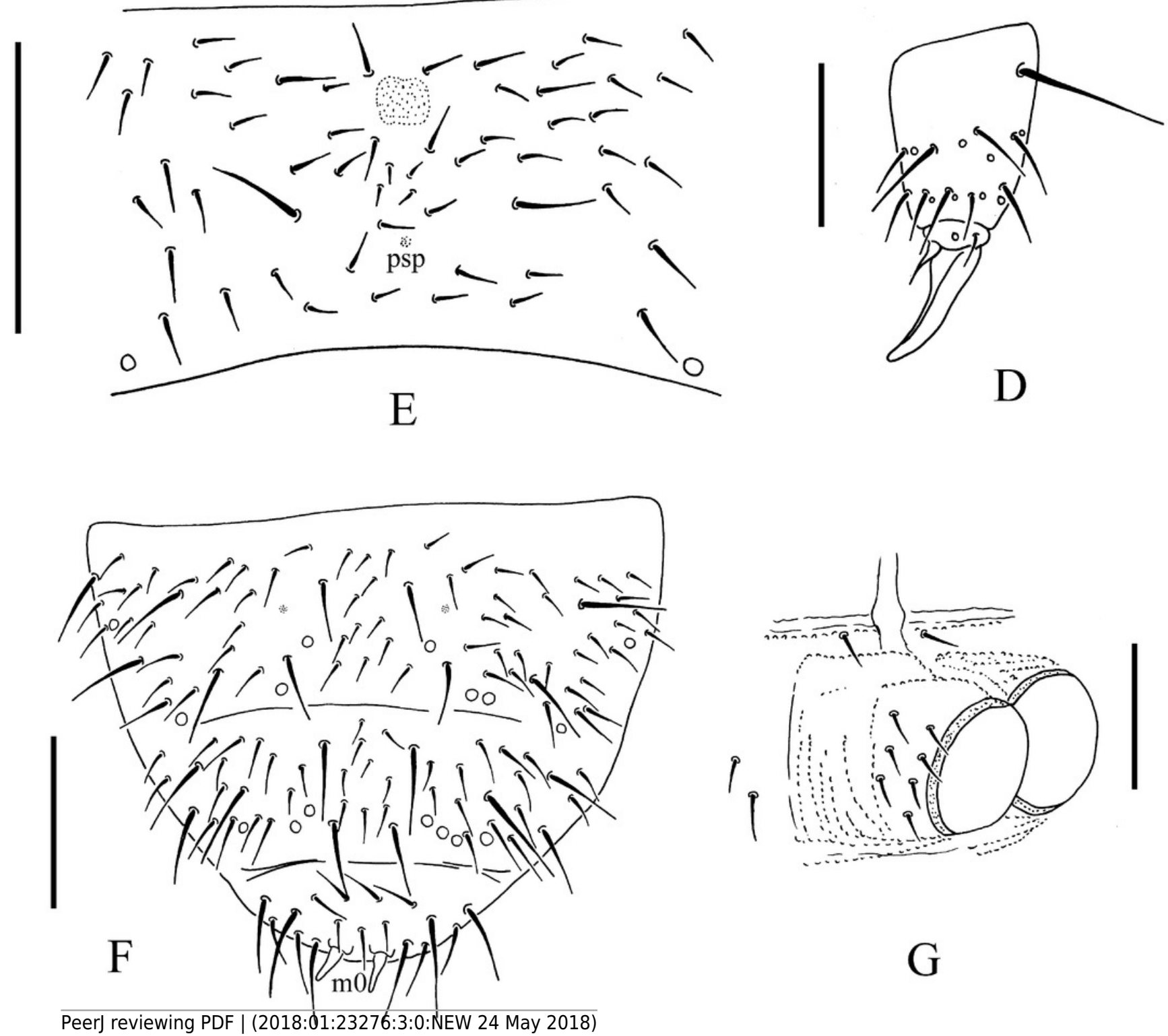


\section{Figure 5}

Thalassaphorura thalassophila.

(A) Habitus, pseudopores and dorsal chaetotaxy of head and body. (B) Labium. (C)

Postantennal organ. (D) Ant. III sensory organ. (E) Th. I tergum. (F) Abd. II-VI sterna. Scales:

$0.1 \mathrm{~mm}(\mathrm{~A}, \mathrm{~F}), 0.05 \mathrm{~mm}(\mathrm{E}), 0.01 \mathrm{~mm}(\mathrm{~B}, \mathrm{C}, \mathrm{D})$. 


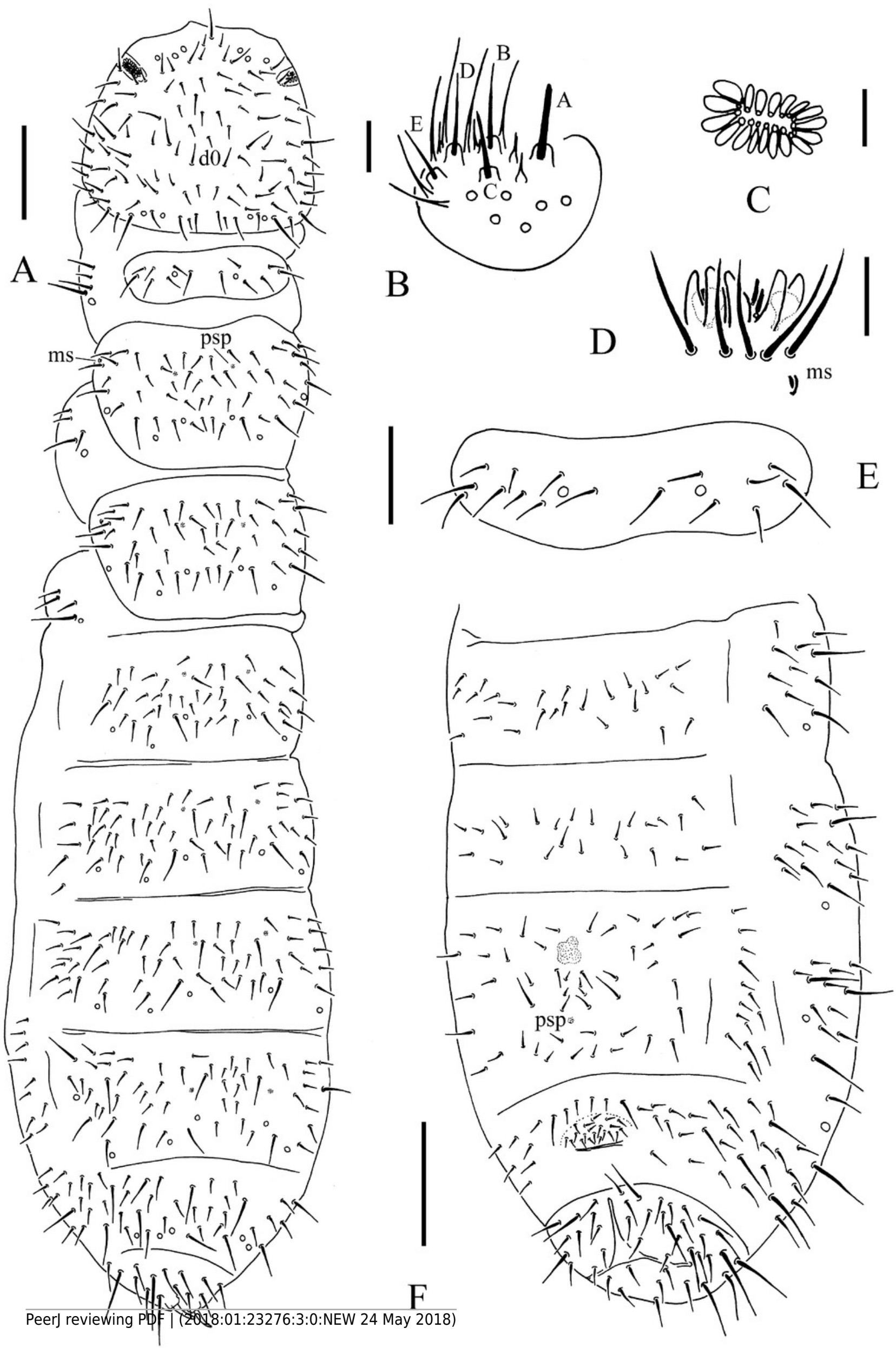




\section{Figure 6}

Thalassaphorura thalassophila

(A) Ventral side of head. (B) Tibiotarsal chaetotaxy and claw of leg I. (C) Tibiotarsal chaetotaxy and claw of leg III. (D) Tibiotarsal chaetotaxy and claw of leg III (type material).

(E) Abd. IV sternum. (F) Abd. IV-VI terga. (G) Anal valves. Scales: $0.1 \mathrm{~mm}(A, E, F), 0.05 \mathrm{~mm}$ $(B, C, D, G)$. 

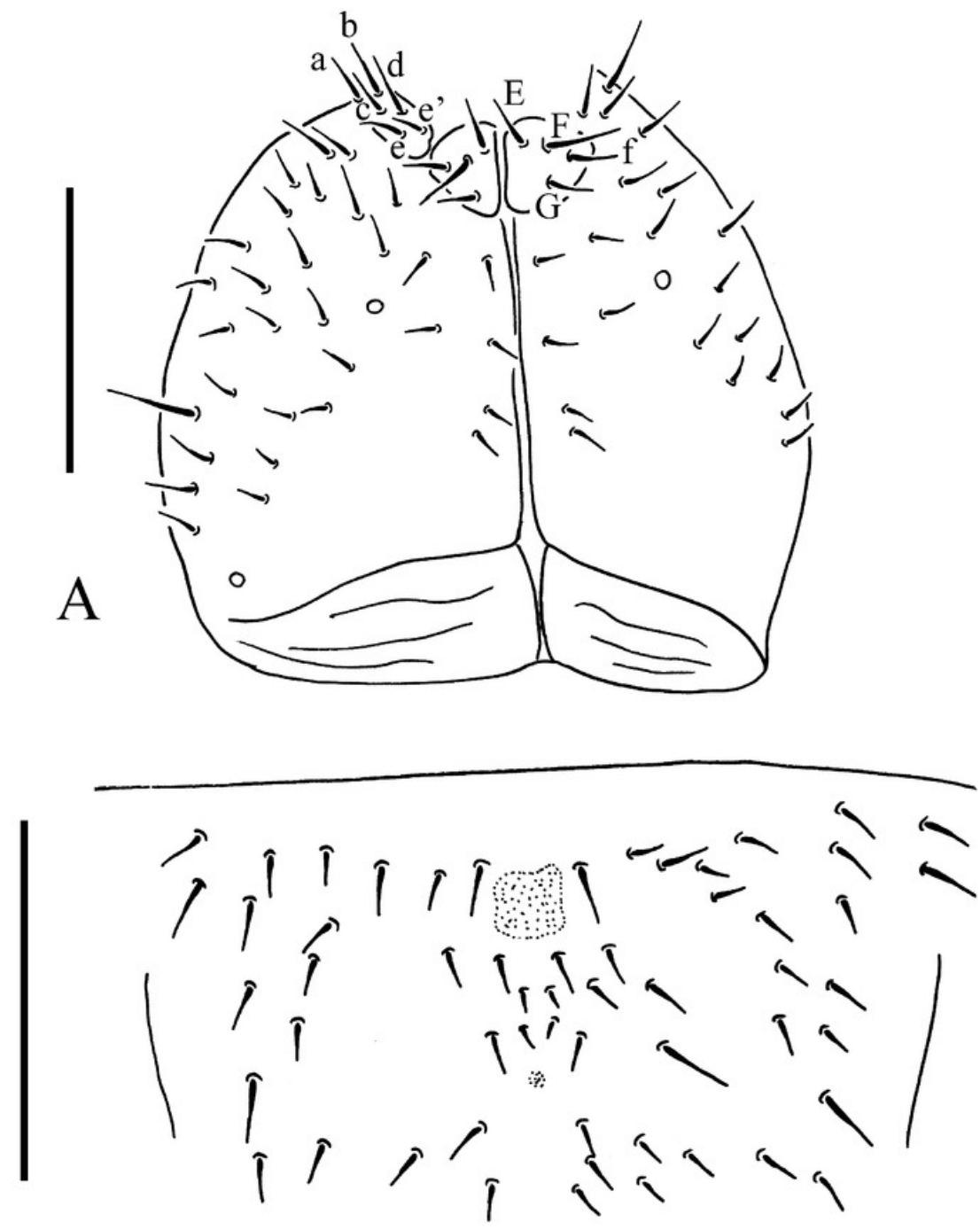

E

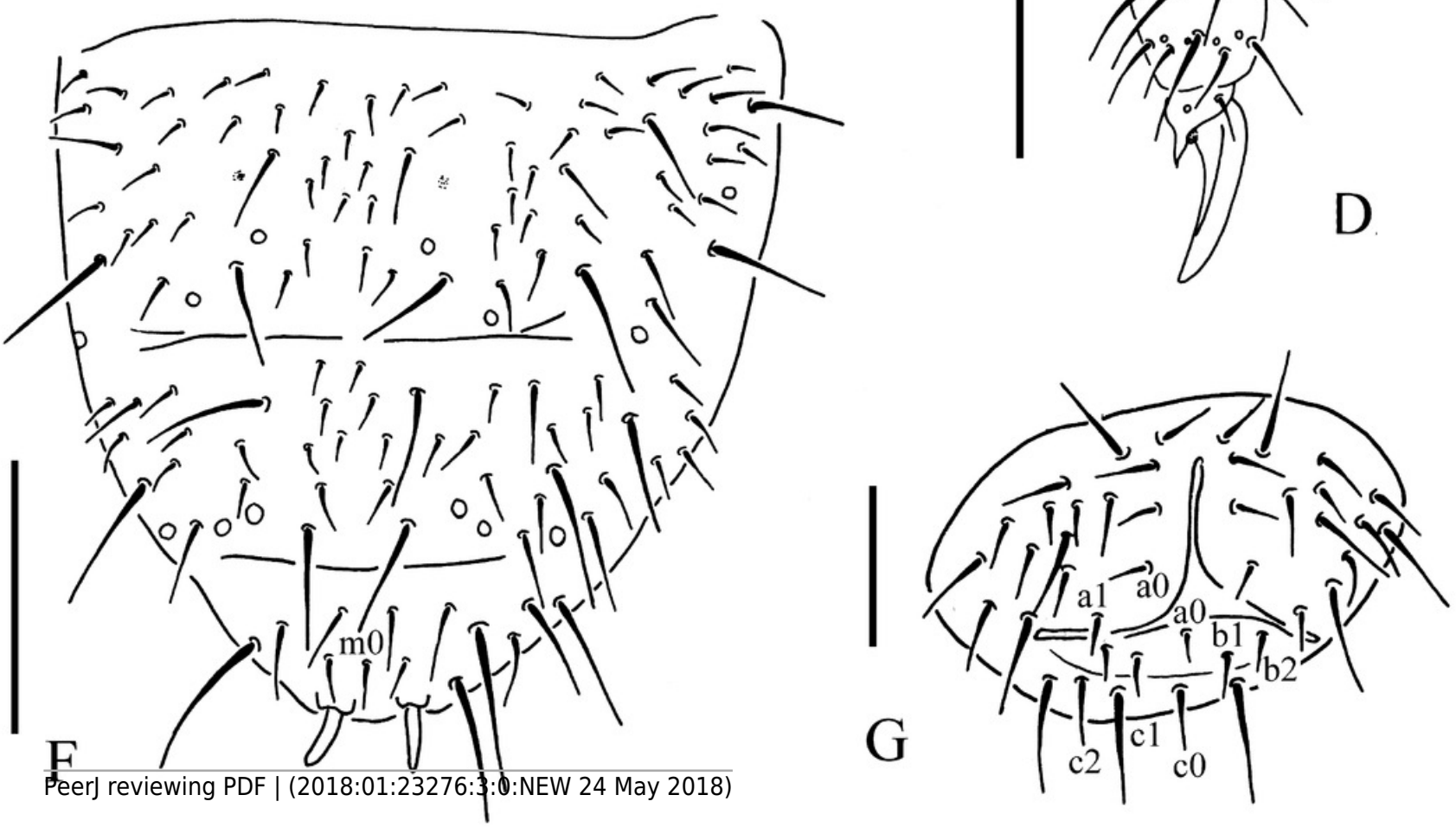


Figure 7

Number of observations (ordinates) for different numbers of PAO vesicles (abscissa) in Thalassaphorura debilis and T. thalassophila.

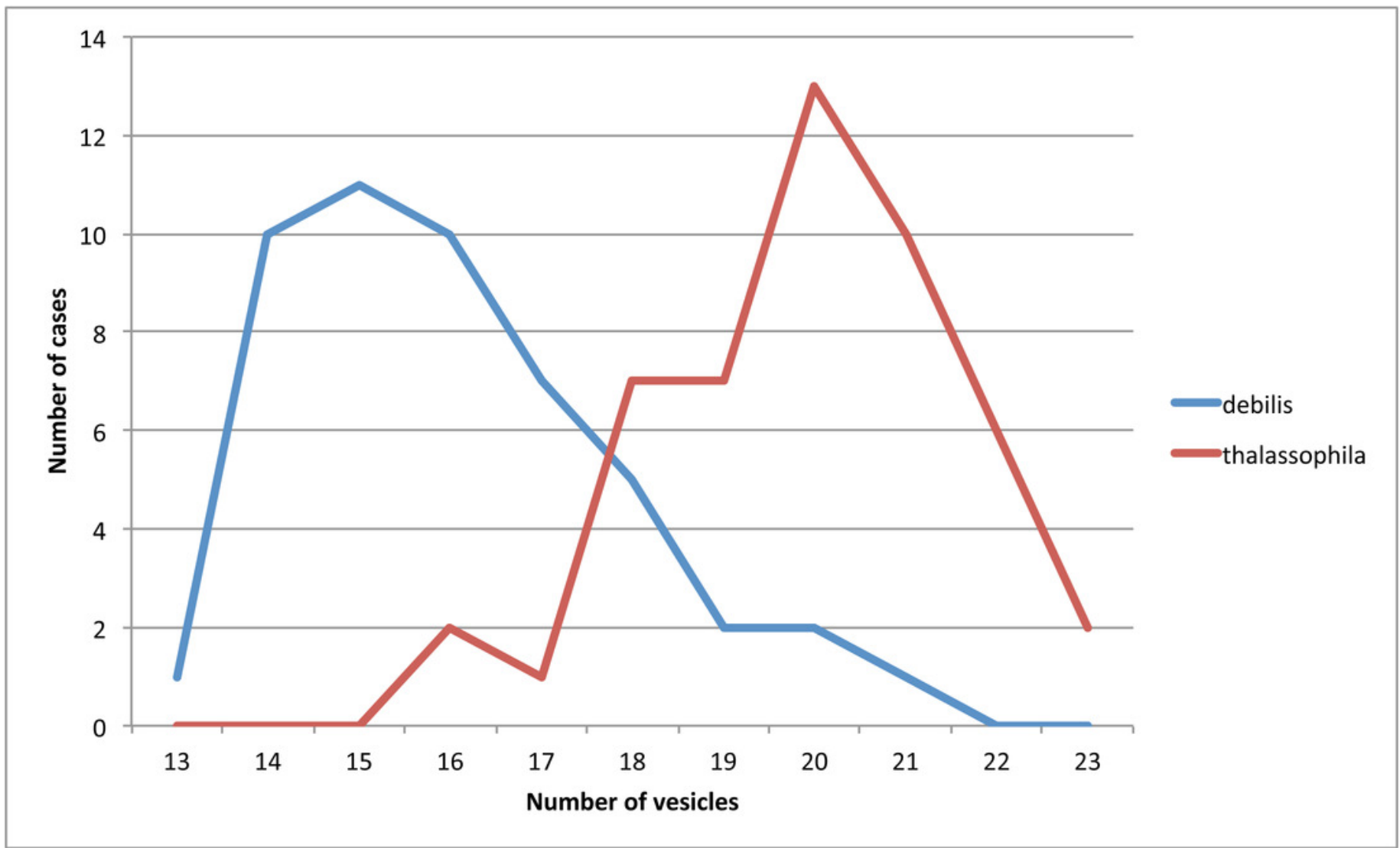


Figure 8

Frequency histogram of K2P pairwise distances.

Columns of the intra-specific divergences are greenish-yellow colored.

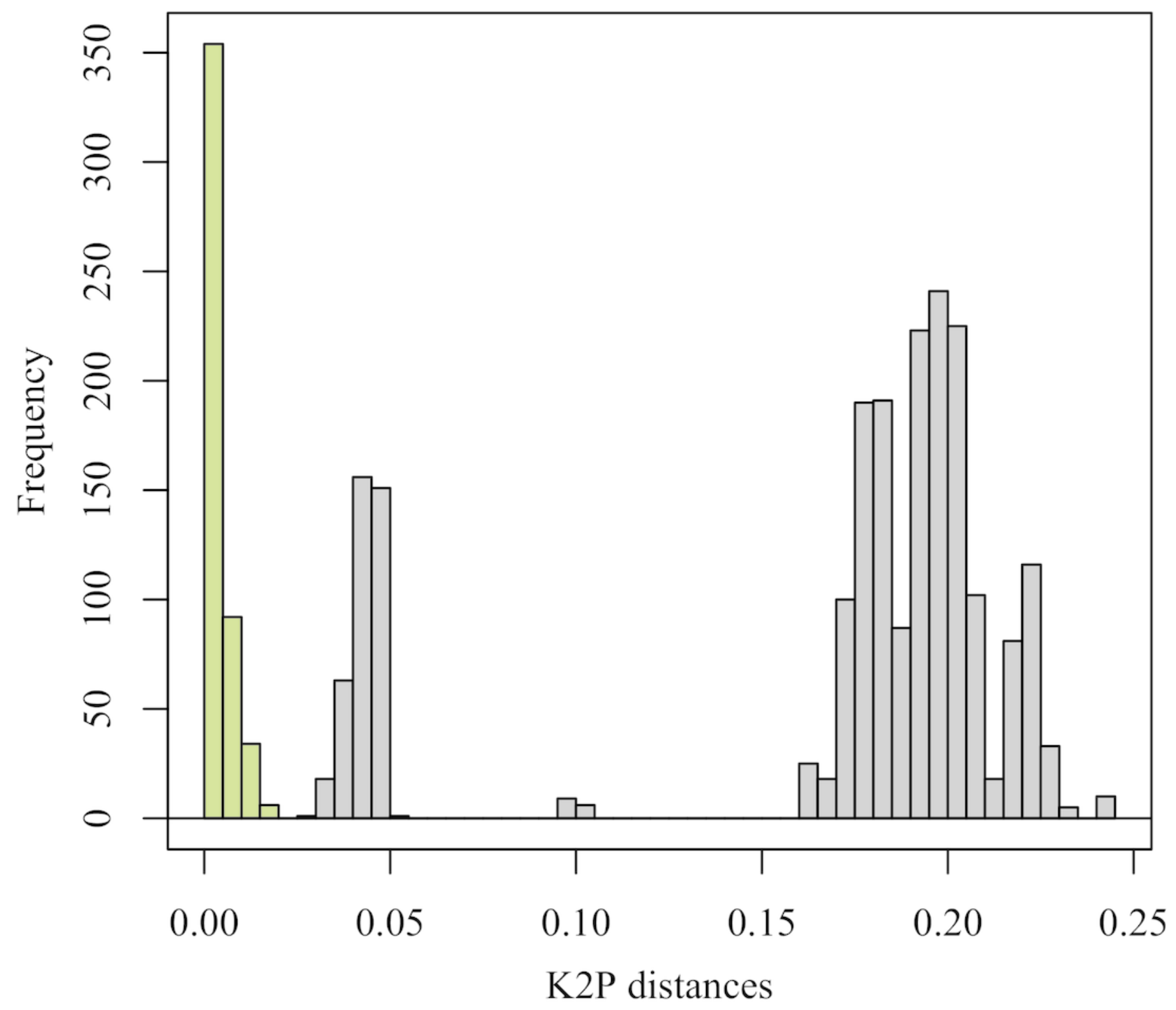




\section{Figure 9}

Neighbour-joining tree (K2P) based on COI for the seven Thalassaphorura species, including three clusters of $T$. zschokkei.

The numbers at MOTU nodes are bootstrap values above $80 \%$ (1000 replicates). TD: the branch of Thalassaphorura debilis and T. thalassophila. 


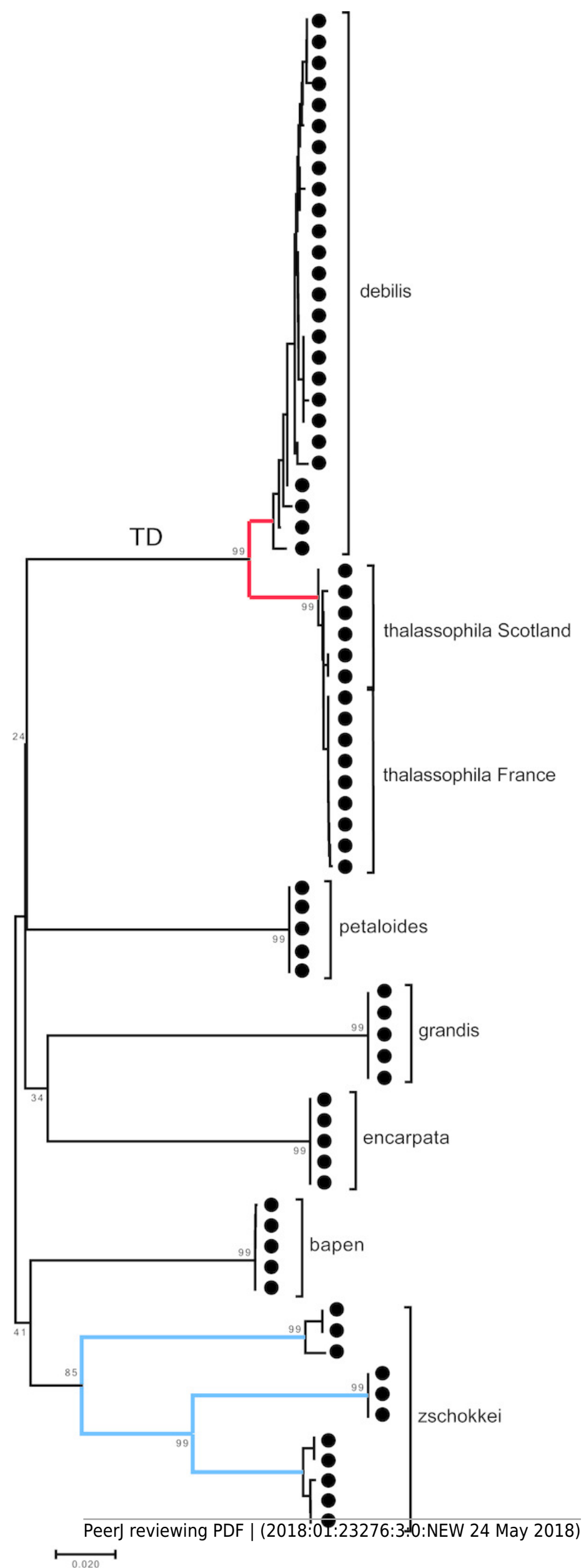


Figure 10

Histograms of COI divergence in \% between species, MOTUs of Thalassaphorura.

In green, between species and populations of the intertidal species debilis - thalassophila, and between three MOTUs of the edaphic species T. zschokkei; in blue, between edaphic species of the genus, and between them and the two intertidal species. b, bapen; d, debilis; e, encarpata; g, grandis; p, petaloides, t, thalassophila; z, zschokkei (with three MOTUs: -1, 2, -3); Fr, France; Sc, Scotland.

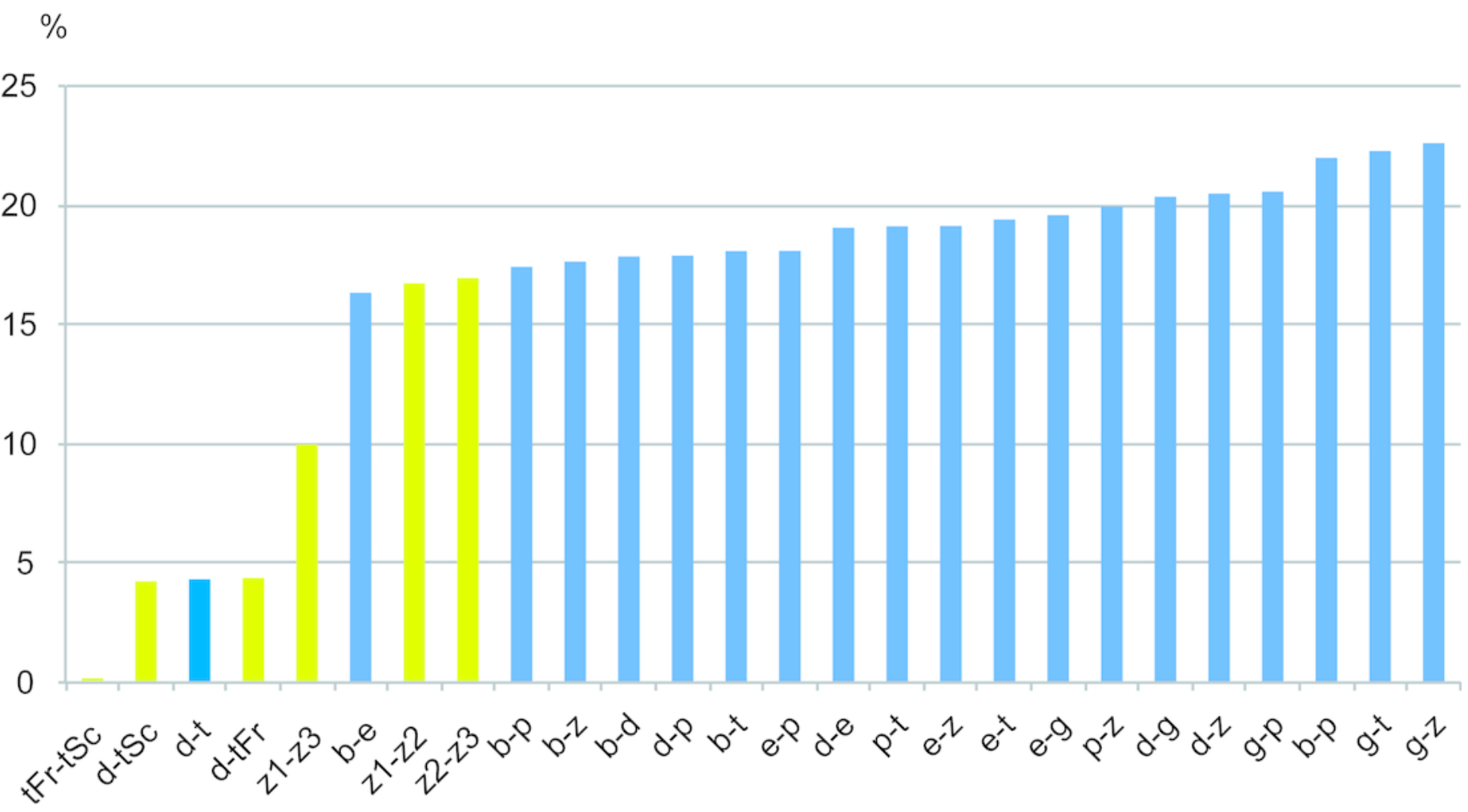




\section{Table $\mathbf{1}$ (on next page)}

Sequence divergence at $\mathrm{COI}$ among Collembola for congeneric species pairs, after literature and the present work.

* Recalculated, Parisotoma notabilis excluded. ** Recalculated, the MOTUs which could not be separated by morphological characters excluded. *** Divergence between $T$. debilis and $T$. thalassophila excluded. 


\begin{tabular}{|c|c|c|c|c|}
\hline Reference & Family & Genus & $\begin{array}{l}\text { Number of } \\
\text { species }\end{array}$ & $\begin{array}{l}\text { Mean } \\
\text { divergence }(\%)\end{array}$ \\
\hline this work & Onychiuridae & $\begin{array}{l}\text { Thalassaphorura } \\
\text { debilis \& thalassophila }\end{array}$ & 2 & 4.3 \\
\hline Katz et al. 2015 & Entomobryidae & Entomobrya & 11 & 17.83 \\
\hline Porco et al. 2012 & Entomobryidae & Heteromurus & 2 & 23.02 \\
\hline Pan, Zhang \& Li, 2015 & Entomobryidae & Homidia & 2 & 18 \\
\hline Porco et al. 2012 & Hypogastruridae & Ceratophysella & 4 & 22.66 \\
\hline Hogg \& Hebert, 2004 & Isotomidae & Folsomia & 4 & 17 \\
\hline Porco et al. $2012^{*}$ & Isotomidae & Parisotoma & 3 & 24.55 \\
\hline Porco et al. 2012 & Neanuridae & Bilobella & 2 & 23.19 \\
\hline Deharveng et al. 2015 & Neanuridae & Deutonura & 4 & 18.95 \\
\hline Porco et al. 2010 & Neanuridae & Deutonura & 5 & 20.25 \\
\hline Porco et al. 2012 & Neanuridae & Deutonura & 4 & 23.24 \\
\hline Sun et al. $2017^{* *}$ & Onychiuridae & Protaphorura & 13 & 16.35 \\
\hline this work $* * *$ & Onychiuridae & Thalassaphorura & 7 & 19.4 \\
\hline Hogg \& Hebert, 2004 & Sminthuridae & Sminthurides & 2 & 21 \\
\hline Porco et al. 2012 & Tomoceridae & Tomocerus & 3 & 19.60 \\
\hline Yu et al. 2016 & Tomoceridae & Tomocerus & 2 & 20.4 \\
\hline Yu, Ding \& Ma, 2017 & Tomoceridae & Tomocerus & 6 & 18.66 \\
\hline
\end{tabular}




\section{Table 2 (on next page)}

Comparison of the main diagnostic characters of $T$. debilis and $T$. thalassophila from different references. 


\begin{tabular}{|c|c|c|c|c|c|c|c|c|}
\hline Source & $\begin{array}{l}\text { current } \\
\text { conception }\end{array}$ & $\begin{array}{l}\text { current } \\
\text { conceptio } \\
\mathrm{n}\end{array}$ & $\begin{array}{l}\text { Moniez } \\
1890 \\
\text { (types) }\end{array}$ & $\begin{array}{l}\text { Denis } 1923 \\
\text { (types) }\end{array}$ & $\begin{array}{l}\text { Willem } \\
1925\end{array}$ & $\begin{array}{l}\text { Jordana } \\
\text { et al. } \\
1997\end{array}$ & $\begin{array}{l}\text { Fjellberg } \\
1998\end{array}$ & $\begin{array}{l}\text { Bagnall } \\
1937\end{array}$ \\
\hline Cited as & T. debilis & $\begin{array}{l}T . \\
\text { thalassop } \\
\text { hila }\end{array}$ & $\begin{array}{l}\text { Lipura } \\
\text { debilis }\end{array}$ & $\begin{array}{l}\text { Onychiurus } \\
\text { debilis }\end{array}$ & $\begin{array}{l}\text { Onychiur } \\
\text { us debilis }\end{array}$ & $\begin{array}{l}\text { Protapho } \\
\text { rura } \\
\text { debilis }\end{array}$ & $\begin{array}{l}\text { Thalassaph } \\
\text { orura } \\
\text { debilis }\end{array}$ & $\begin{array}{l}\text { Onychiur } \\
\text { us } \\
\text { thalassop } \\
\text { hilus }\end{array}$ \\
\hline $\begin{array}{l}\text { Current } \\
\text { name }\end{array}$ & T. debilis & $\begin{array}{l}\text { T. } \\
\text { thalassop } \\
\text { hila } \\
\text { Female }\end{array}$ & $\begin{array}{l}T . \\
\text { debilis }\end{array}$ & T. debilis & T. debilis & $\begin{array}{l}T . \\
\text { thalassop } \\
\text { hila }\end{array}$ & $\begin{array}{l}T . \\
\text { thalassophil } \\
a / \text { debilis }\end{array}$ & $\begin{array}{l}T \text {. } \\
\text { thalassop } \\
\text { hila }\end{array}$ \\
\hline $\begin{array}{l}\text { Length } \\
(\mathrm{mm})\end{array}$ & $\begin{array}{l}\text { Female } \\
1.4-2.1, \\
\text { male } 1.4- \\
1.65\end{array}$ & $\begin{array}{l}1.32- \\
1.93, \\
\text { male } \\
1.20- \\
1.66\end{array}$ & $1.1-1.2$ & $<1.5$ & 0.95 & 1.5 & 1.4 & 1.5 \\
\hline PAO & $13-21$ & $16-23$ & $23-28$ & $19-20$ & 17 & $18-19$ & $15-20$ & $16-20$ \\
\hline $\begin{array}{l}\text { Dorsal pso } \\
\text { formula }\end{array}$ & $\begin{array}{l}32 / 1- \\
233 / 3,3- \\
4,3,4-6,3-4\end{array}$ & $\begin{array}{l}32 / 133 / 3 \\
3343\end{array}$ & $\begin{array}{l}? 2 / 2 ? ? / ? \\
? ? ? 4\end{array}$ & $\begin{array}{l}32 / 1 \geq 2 \geq 3 / \geq 2 \geq 2 \\
\geq 2 \geq 23\end{array}$ & $\begin{array}{l}32 / 133 / 3 \\
3354\end{array}$ & $\begin{array}{l}32 / 133 / 3 \\
3343\end{array}$ & $\begin{array}{l}32 / 133 / 333 \\
43\end{array}$ & $\begin{array}{l}32 / 133 / 33 \\
343\end{array}$ \\
\hline $\begin{array}{l}\text { Ventral pso } \\
\text { formula }\end{array}$ & $\begin{array}{l}11 / 000 / 011 \\
1(2) 0\end{array}$ & $\begin{array}{l}11 / 000 / 0 \\
0000\end{array}$ & $?$ & $?$ & $?$ & $\begin{array}{l}11 / 000 / 0 \\
0000\end{array}$ & $\begin{array}{l}11 / 000 / 000 \\
00\end{array}$ & $\begin{array}{l}11 / 000 / 00 \\
000\end{array}$ \\
\hline $\begin{array}{l}\text { pso on } \\
\text { subcoxae I- } \\
\text { III }\end{array}$ & 222 & 111 & 222 & $?$ & 111 & 111 & 111 & 111 \\
\hline $\begin{array}{l}\text { Axial } \\
\text { chaetae on } \\
\text { Abd.VI }\end{array}$ & $\mathrm{m} 0$ & $\mathrm{~m} 0(\mathrm{a} 0)$ & $?$ & $?$ & $?$ & $\mathrm{~m} 0$ & 1 or 2 & $\mathrm{a} 0$ \\
\hline $\begin{array}{l}\text { Ratio of } \\
\text { AS/clawIII }\end{array}$ & $0.47-0.77$ & $0.68-1.08$ & $0.5-0.6$ & $\geq 0.5$ & 0.6 & 0.7 & $\begin{array}{l}\text { variable in } \\
\text { size }\end{array}$ & $0.62-0,86$ \\
\hline $\begin{array}{l}\text { Head ventral } \\
\text { chaetae } \\
\text { along groove }\end{array}$ & $4+4$ & $3+3$ & $?$ & $?$ & $?$ & $?$ & $4-5+4-5$ & $3+3$ \\
\hline $\begin{array}{l}\text { Chaetae on } \\
\text { ventral tube } \\
\text { (anterior } \\
\text { /distal /basal } \\
\text { chaetae) }\end{array}$ & $\begin{array}{l}1+1 / 7+7(8) \\
/ 2+2\end{array}$ & $\begin{array}{l}1+1 / 7+7 / \\
2+2\end{array}$ & $?$ & $?$ & $?$ & $\begin{array}{l}1+1 / 7- \\
8+7- \\
8 / 2+2\end{array}$ & $\begin{array}{l}1+1(2) / 7- \\
8+7-8 / 1- \\
4+1-4\end{array}$ & $\begin{array}{l}1+1 / 7+7 / \\
2+2\end{array}$ \\
\hline $\begin{array}{l}\text { Ratio of } \\
\text { unguiculus/u } \\
\text { nguis }\end{array}$ & $0.27-0.47$ & 0.2 & $0.3-0.4$ & 0.4 & 0.4 & $\begin{array}{l}\text { short, } \\
\leq 0.25 \\
\text { after } \\
\text { original } \\
\text { drawing }\end{array}$ & $\begin{array}{l}\text { variable in } \\
\text { size, mostly } \\
0.5\end{array}$ & $\begin{array}{l}\text { vestigial, } \\
\text { reduced } \\
\text { to a } \\
\text { minute, } \\
\text { stumpy } \\
\text { process }\end{array}$ \\
\hline $\begin{array}{l}\text { Chaetae on } \\
\text { subcoxae } 1 \\
\text { of legs I-III }\end{array}$ & $\begin{array}{l}4-5,4-5, \\
4-5\end{array}$ & 444 & $4 / 4-5 / ?$ & $?$ & $?$ & $4 / 4 / ?$ & $?$ & $4(3) 44$ \\
\hline Location & $\begin{array}{l}\text { France: } \\
\text { Pointe-aux- } \\
\text { oies }\end{array}$ & $\begin{array}{l}\text { France: } \\
\text { Pointe- } \\
\text { aux-oies; } \\
\text { Scotland: } \\
\text { Dalmeny }\end{array}$ & $\begin{array}{l}\text { France: } \\
\text { Pointe- } \\
\text { aux-oies }\end{array}$ & $\begin{array}{l}\text { France: Pointe- } \\
\text { aux-oies }\end{array}$ & $\begin{array}{l}\text { France: } \\
\text { Pointe- } \\
\text { aux-oies }\end{array}$ & $\begin{array}{l}\text { Spain: } \\
\text { Ponteved } \\
\text { ra coast }\end{array}$ & $\begin{array}{l}\text { Norwegian } \\
\text { and Danish } \\
\text { coast }\end{array}$ & $\begin{array}{l}\text { Scotland: } \\
\text { Dalmeny }\end{array}$ \\
\hline
\end{tabular}




\section{Table 3(on next page)}

Intraspecific and intra-MOTUs divergence within the genus Thalassaphorura. 


\begin{tabular}{ll}
\hline Species & Intraspecific divergence \\
\hline Thalassaphorura grandis & 0 \\
Thalassaphorura debilis & 0.004900574 \\
Thalassaphorura thalassophila & 0.001593864 \\
Thalassaphorura petaloides & 0 \\
Thalassaphorura bapen & 0 \\
Thalassaphorura zschokkei & 0.102789204 \\
Thalassaphorura encarpata & 0 \\
\hline
\end{tabular}

1 


\section{Table 4 (on next page)}

Molecular divergence (COI) between Thalassaphorura species (A), between populations of the $T$. debilis-T. thalassophila group (B), and between three populations of $T$. zschokkei (C). FR, France; SC, Scotland. 


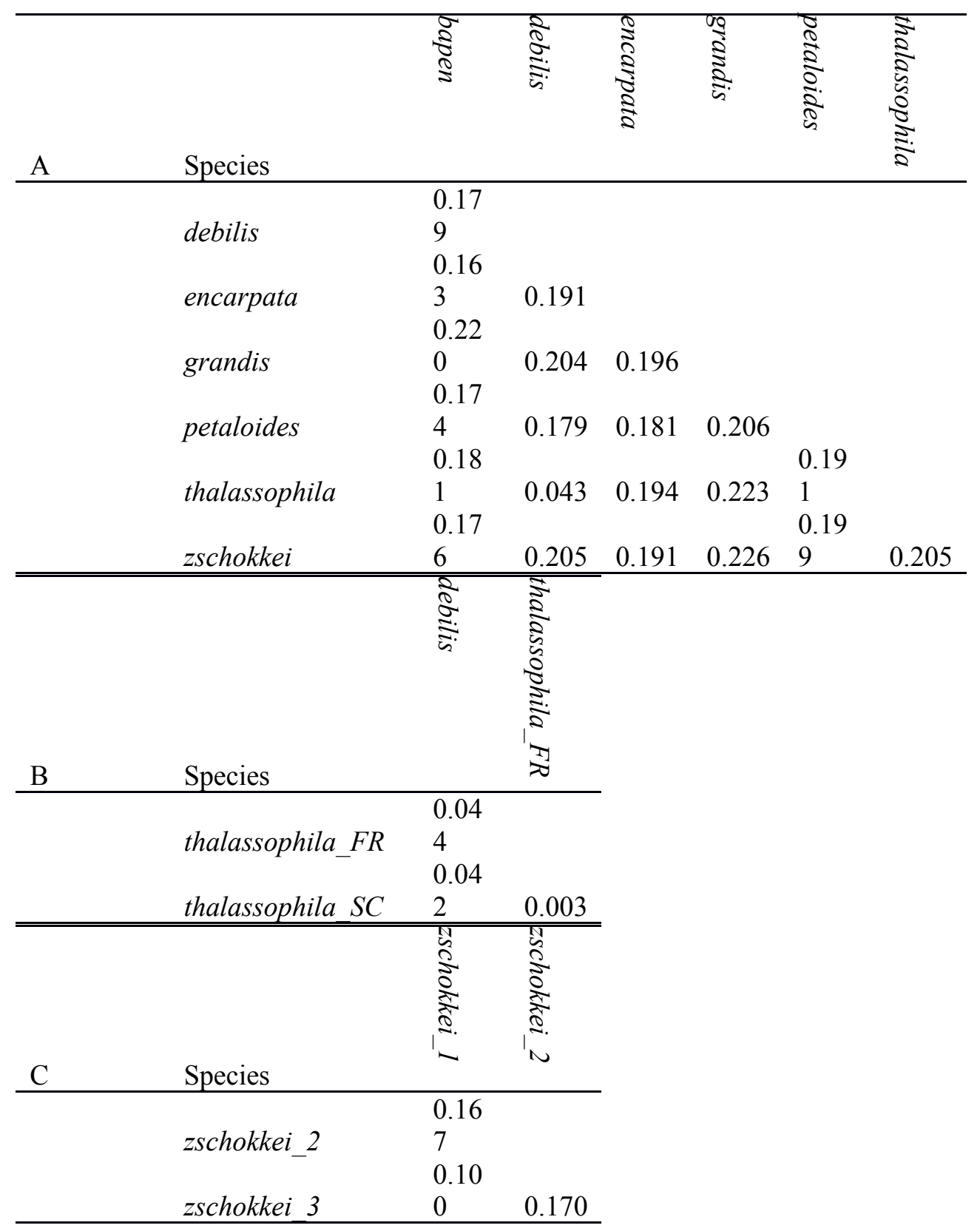

